\title{
Octadentate Zirconium(IV)-Loaded Macrocycles with Varied Stoichiometry Assembled From Hydroxamic Acid Monomers using Metal-Templated Synthesis
}

\author{
William Tieu, ${ }^{\dagger}$ Tulip Lifa, ${ }^{\dagger}$ Andrew Katsifis, ${ }^{\dagger}$ and Rachel Codd ${ }^{*}{ }^{\dagger}$ (1) \\ ${ }^{\dagger}$ School of Medical Sciences (Pharmacology) and Bosch Institute, The University of Sydney, New South Wales 2006, Australia \\ ${ }^{\ddagger}$ Department of Molecular Imaging, Royal Prince Alfred Hospital, Camperdown, New South Wales 2050, Australia
}

Supporting Information

ABSTRACT: The reaction between $\operatorname{Zr}(\mathrm{IV})$ and the forward endo-hydroxamic acid monomer 4-[(5-aminopentyl)(hydroxy)amino]-4-oxobutanoic acid (for-PBH) in a $1: 4$ stoichiometry in the presence of diphenylphosphoryl azide and triethylamine gave the octadentate $\mathrm{Zr}(\mathrm{IV})$-loaded tetrameric hydroxamic acid macrocycle for-[ $\left.\mathrm{Zr}\left(\mathrm{DFOT}_{1}\right)\right]$ $\left([\mathrm{M}+\mathrm{H}]^{+}\right.$calc 887.3, obs 887.2). In this metal-templated synthesis (MTS) approach, the coordination preferences of $\mathrm{Zr}(\mathrm{IV})$ directed the preorganization of four oxygen-rich bidentate for-PBH ligands about the metal ion prior to ring closure under peptide coupling conditions. The replacement of for-PBH with 5-[(5-aminopentyl) (hydroxy)amino]-5-oxopentanoic acid (for-PPH), which contained an additional

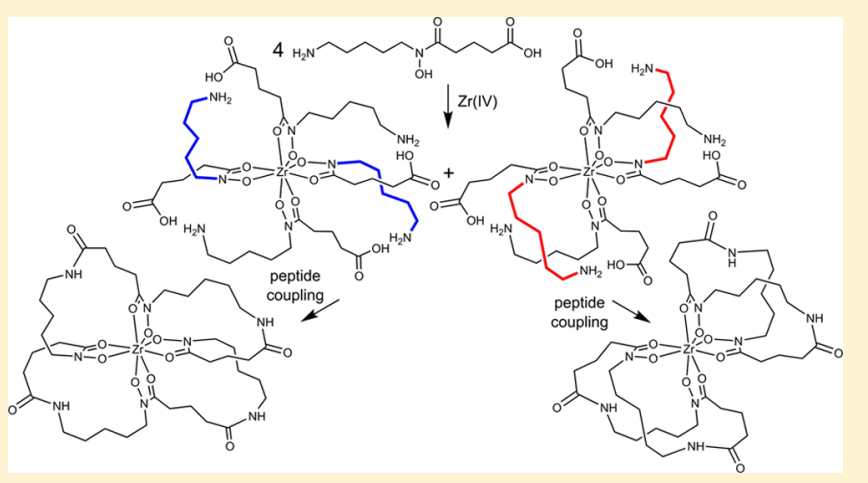
methylene group in the dicarboxylic acid region of the monomer, gave the analogous $\mathrm{Zr}(\mathrm{IV})$-loaded macrocycle for$\left[\mathrm{Zr}\left(\mathrm{PPDFOT}_{1}\right)\right]\left([\mathrm{M}+\mathrm{H}]^{+}\right.$calc 943.4, obs 943.1). A second, well-resolved peak in the liquid chromatogram from the for-PPH MTS system also characterized as a species with $[\mathrm{M}+\mathrm{H}]^{+}$943.3, and was identified as the octadentate complex between $\mathrm{Zr}(\mathrm{IV})$ and two dimeric tetradentate hydroxamic acid macrocycles for $\left[\mathrm{Zr}\left(\mathrm{PPDFOT}_{1 \mathrm{D}}\right)_{2}\right]$. Treatment of for-[Zr(PPDFOT 1$\left.)\right]$ or for$\left[\mathrm{Zr}\left(\mathrm{PPDFOT}_{1 \mathrm{D}}\right)_{2}\right]$ with EDTA at $\mathrm{pH} 4.0$ gave the respective hydroxamic acid macrocycles as free ligands: octadentate $\mathrm{PPDFOT}_{1}$ or two equivalents of tetradentate PPDFOT ${ }_{1 \mathrm{D}}$ (homobisucaberin, $\mathrm{HBC}$ ). At $\mathrm{pH}$ values closer to physiological, EDTA treatment of for-[ $\left.\mathrm{Zr}\left(\mathrm{DFOT}_{1}\right)\right]$, for $-\left[\mathrm{Zr}\left(\mathrm{PPDFOT}_{1}\right)\right]$, or $\mathrm{Zr}(\mathrm{IV})$ complexes with related linear tri- or tetrameric hydroxamic acid ligands showed the macrocycles were more resistant to the release of $\mathrm{Zr}(\mathrm{IV})$, which has implications for the design of ligands optimized for the use of $\mathrm{Zr}(\mathrm{IV})-89$ in positron emission tomography (PET) imaging of cancer.

\section{INTRODUCTION}

Good clinical decision making in the diagnosis and management of patients with cancer is supported by access to highdefinition images of the tumor with positron emission tomography (PET) imaging in wide use for this purpose. ${ }^{1-4}$ Zirconium- 89 has been under recent scrutiny as a radionuclide with properties that show promise for its use in antibodycoupled PET imaging. ${ }^{5-9}$ The half-life of $\mathrm{Zr}-89$ (3.27 d, $\beta^{+}=$ $22.7 \%$, maximum $\beta^{+}$energy $=0.897 \mathrm{MeV}$ ) is well-matched to the circulation half-life of antibodies, which makes $\mathrm{Zr}-89$ attractive for immunological PET applications designed to concentrate the radionuclide at the site of the antigenexpressing tumor to improve the tumor-to-nontumor signal and the image resolution. ${ }^{9-12}$ Progressing preclinical and clinical evaluation of $\mathrm{Zr}-89$ as a PET radionuclide would benefit from a ligand suitably tailored to bind $\mathrm{Zr}$ (IV) with high affinity and selectivity. As a hard acid, $\operatorname{Zr}(\mathrm{IV})$ favors coordination with ligands rich in oxygen donor atoms, ${ }^{13}$ which include hydroxamic acids. ${ }^{14-16}$ The linear trimeric hydroxamic acid desferrioxamine B (Chart 1, 1, DFOB), which is a metabolite of the siderophore class produced for $\mathrm{Fe}(\mathrm{III})$ acquisition by many Streptomyces species, ${ }^{17-19}$ has been used to coordinate $\mathrm{Zr}-89$ in a number of preclinical and clinical studies, ${ }^{20-27}$ although as a hexadentate ligand, it is unable to saturate the preferred octadentate $\mathrm{Zr}(\mathrm{IV})$ coordination sphere. $^{28}$ The complex $\left[\mathrm{Zr}(\mathrm{DFOB})\left(\mathrm{OH}_{2}\right)_{2}\right]^{+}$(Chart 1, 2) ${ }^{15,29}$ has only modest in vivo stability, which can result in the release and deposition of some of the radionuclide in nontargeted organs, and a reduction in the image quality. ${ }^{29-31}$

In recent work, ${ }^{32,33}$ the DFOB scaffold was improved as a $\mathrm{Zr}(\mathrm{IV})$ ligand by undertaking a chain-extension reaction between DFOB and the endo-hydroxamic acid monomer 4[(5-aminopentyl)(hydroxy)amino]-4-oxobutanoic acid (for$\mathrm{PBH}$ ), which is a biosynthetic fragment of desferrioxaminetype siderophores. ${ }^{34-37}$ This produced a linear octadentate tetrameric hydroxamic acid ligand DFOB-for-PBH that formed [Zr(DFOB-for-PBH)] (Chart 1, 3), which was more stable to

Received: February 9, 2017

Published: February 28, 2017 
Chart 1. Desferrioxamine B (DFOB) (1) and Its Complex with $\mathrm{Zr}(\mathrm{IV})(2)^{a}$
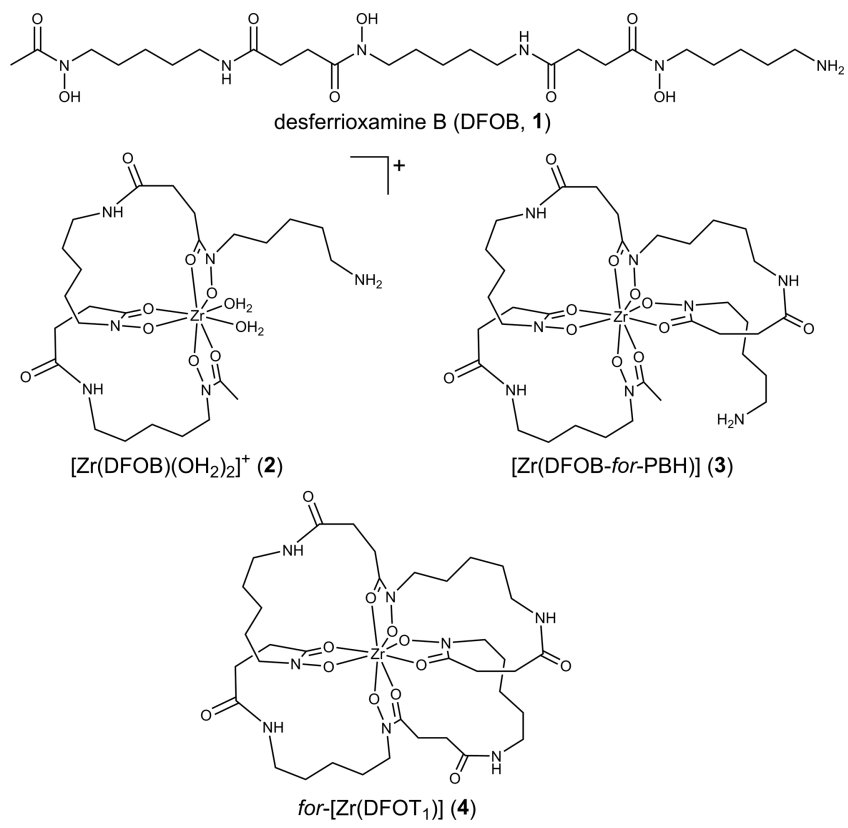

${ }^{a}$ Complexes between $\mathrm{Zr}(\mathrm{IV})$ and a linear (3) or macrocyclic (4) chain-extended variant of DFOB.

$\mathrm{Zr}(\mathrm{IV})$ release than $\left[\mathrm{Zr}(\mathrm{DFOB})\left(\mathrm{OH}_{2}\right)_{2}\right]^{+}$(2). Complexes between $\mathrm{Zr}(\mathrm{IV})$ and other linear octadentate hydroxypyridinonate (HOPO)-type hydroxamic acid ligands ${ }^{38-40}$ or a DFOBsquaramide ligand ${ }^{41}$ have also been characterized. The current work considered that a further gain in the stability of the $\mathrm{Zr}$ (IV) complex could result if the octadentate DFOB-type tetrameric hydroxamic acid ligand was configured into a macrocycle (Chart 1, 4). This principle was supported by a study of macrocycles designed to coordinate $\mathrm{Zr}(\mathrm{IV})$ that were cyclized from hydrophobic abiological tetrameric linear constructs using ring-closing metathesis, ${ }^{42}$ and from other studies focused upon developing macrocycles for $\mathrm{Zr}-89$ PET imaging. ${ }^{43}$

The current work has used a metal-templated synthesis (MTS) approach to examine the ability of $\mathrm{Zr}(\mathrm{IV})$ to assemble its own best macrocycle from a selection of hydroxamic acid monomers reminiscent of the fragments used in siderophore biosynthesis. The stability of these macrocycles in retaining $\mathrm{Zr}(\mathrm{IV})$ could be reasonably compared to the linear tetrameric hydroxamic acid ligand DFOB-for-PBH, and trimeric DFOB. The use of a metal ion to template the assembly of its ideal coordination complex from a pool of fragment ligands that contain reactive termini is attractive in its simplicity, and offers the potential to deliver macrocycles with high affinity and selectivity. ${ }^{44,45}$ Metal-templated synthesis (MTS) with Fe(III) or $\mathrm{Ga}(\mathrm{III})$ as the template has been used to assemble the trimeric hydroxamic acid macrocycle desferrioxamine $\mathrm{E}$ (DFOE) from for- $\mathrm{PBH} .{ }^{46}$ Other metal-loaded ring-expanded desferrioxamine-type macrocyclic siderophores have since been assembled using $\mathrm{Fe}$ (III) or Ga(III)-based MTS from a range of endo-hydroxamic acid monomers, including forward (for- = $\left.\mathrm{H}_{2} \mathrm{~N}-\left(\mathrm{CH}_{2}\right)_{x}-\mathrm{N}(\mathrm{OH}) \mathrm{C}(\mathrm{O})-\left(\mathrm{CH}_{2}\right)_{y}-\mathrm{CO}_{2} \mathrm{H}\right)$ and reverse (ret- $\left.=\mathrm{H}_{2} \mathrm{~N}-\left(\mathrm{CH}_{2}\right)_{x}-\mathrm{C}(\mathrm{O}) \mathrm{N}(\mathrm{OH})-\left(\mathrm{CH}_{2}\right)_{y}-\mathrm{CO}_{2} \mathrm{H}\right) \quad$ ligands. $^{47}$

In this work, the utility of MTS for assembling $\mathrm{Zr}$ (IV) macrocycles as constructs with potential relevance for $\mathrm{Zr}(\mathrm{IV})$ -
89 PET imaging is reported. The importance of macrocycles in drug design, ${ }^{48-51}$ warrants the development of new methods for the streamlined production of structurally diverse macrocycles. $^{52,53}$

\section{RESULTS AND DISCUSSION}

Synthesis of endo-Hydroxamic Acid Ligands. A series of six endo-hydroxamic acid amino carboxylic acid monomers were prepared using reported methods: for-PBH, for-PPH, for$\mathrm{HBH}$, ret-PBH and ret-HBH. ${ }^{47}$ The monomer 4-(6-amino- $N$ hydroxyhexanamido)butanoic acid (ret-PPH) was prepared in a fashion similar to ret-PBH, with the substitution of tert-butyl-3[(benzyloxy)amino]propanoate with ethyl-4-[benzyloxy)amino]butanoate (Scheme S1 and Figures S1-S6). The first letter in the nomenclature system for these ligands denotes the component derived from either pentane-1,5-diamine $(\mathrm{P})$ or hexane-1,6-diamine $(\mathrm{H})$, with the second letter referring to the component derived from butandioic acid (B) or pentandioic acid (P). The terminal ' $\mathrm{H}$ ' is reference to the acidic proton of the hydroxamic acid. Native siderophores are assembled from forward (for-) endo-hydroxamic acids, which feature the internal $-\mathrm{N}(\mathrm{OH}) \mathrm{C}(\mathrm{O})$ - motif inserted in the direction as written, between the amine terminus and the carboxylic acid terminus. The reverse or retro (ret-) analogues feature the hydroxamic acid insert in the reverse orientation: $-\mathrm{C}(\mathrm{O}) \mathrm{N}$ $(\mathrm{OH})$-. This work sought to determine whether $\mathrm{Zr}(\mathrm{IV})$ demonstrated a preference in the MTS-directed assembly of macrocycles from ligands that differed in length and thereby cavity size, as defined by the number of internal main-chain atoms $(\mathrm{PBH}, 10 ; \mathrm{PPH}$ and $\mathrm{HBH}, 11)$; the position of the additional methylene group, as inserted in the diamine region $(\mathrm{HBH})$ or the dicarboxylic acid region $(\mathrm{PPH})$; and the orientation of the hydroxamic acid group (for-, ret-), which could affect the electronic structure and the physicochemical properties of the macrocycle (Scheme 1).

LC-MS Data From Zr(IV)-Based MTS Reaction Solutions. Standard MTS experiments involved the reaction between $\mathrm{Zr}(\mathrm{IV})$ and a given ligand (e.g., for- $\mathrm{PBH}$ ) in a 1:4 ratio in a solution of 1:1 methanol:water to form the preassembled complex, with ring closure effected after a 5-d reaction time with diphenylphosphoryl azide (DPPA) and triethylamine. A series of three native tetrameric hydroxamic acid macrocycles has been characterized from cultures of Erwinia amylovora, with the macrocycle assembled from for-PBH named DFOT $1 .{ }^{54}$ This naming system has been used here. The LC trace from the $\mathrm{Zr}(\mathrm{IV})$-for-PBH MTS system showed a single peak (SIM 887) at $t_{\mathrm{R}} 29.7 \mathrm{~min}$ (Figure 1a), which in the MS gave an isotope pattern (Figure $2 \mathrm{a}$ ) consistent with the calculated patterns (Figure $2 \mathrm{~d}$ ) of the $[\mathrm{M}+2 \mathrm{H}]^{2+},[\mathrm{M}+\mathrm{H}]^{+}$, and $[\mathrm{M}+\mathrm{Na}]^{+}$ adducts of for- $\left[\mathrm{Zr}\left(\mathrm{DFOT}_{1}\right)\right](4)$ (Scheme 1$)$. The presence of $\mathrm{Zr}(\mathrm{IV})$ in the macrocycle was clear from the characteristic isotope pattern of natural $\mathrm{Zr}\left({ }^{90} \mathrm{Zr} 51.45,{ }^{91} \mathrm{Zr} 11.22,{ }^{92} \mathrm{Zr} 17.15\right.$, $\left.{ }^{94} \mathrm{Zr} \mathrm{17.38,}{ }^{96} \mathrm{Zr} 2.80\right)$. Two other species were identified from the $\mathrm{Zr}(\mathrm{IV})$-for-PBH MTS system, including the $\mathrm{Zr}(\mathrm{IV})$ complex formed with the linear tetrameric ligand $\left([\mathrm{M}+\mathrm{H}]^{+}\right.$ calc 905.4, obs 905.1), as the precursor of for-[ $\left.\mathrm{Zr}\left(\mathrm{DFOT}_{1}\right)\right]$ (4), and a trimeric $\mathrm{Zr}(\mathrm{IV})$-loaded macrocycle $\left([\mathrm{M}]^{+}\right.$calc 687.2, obs 687.1). The latter species was confirmed as $[\mathrm{Zr}(\mathrm{DFOE})]^{+}$ (with labile ancillary ligands $\left(\mathrm{eg}, \mathrm{H}_{2} \mathrm{O}\right)$ likely displaced during the MS procedure) from its coelution with an authentic sample of $[\mathrm{Zr}(\mathrm{DFOE})]^{+}$(Figure S7). No macrocycles were detected from a DPPA and triethylamine solution containing for- $\mathrm{PBH}$ in 
Scheme 1. $\mathrm{Zr}$ (IV)-Templated Synthesis of Tetrameric Macrocycles 4-9 from the Cognate Monomers for-PBH, for$\mathrm{PPH}$, for-HBH, ret-PBH, ret-PPH, or ret-HBH
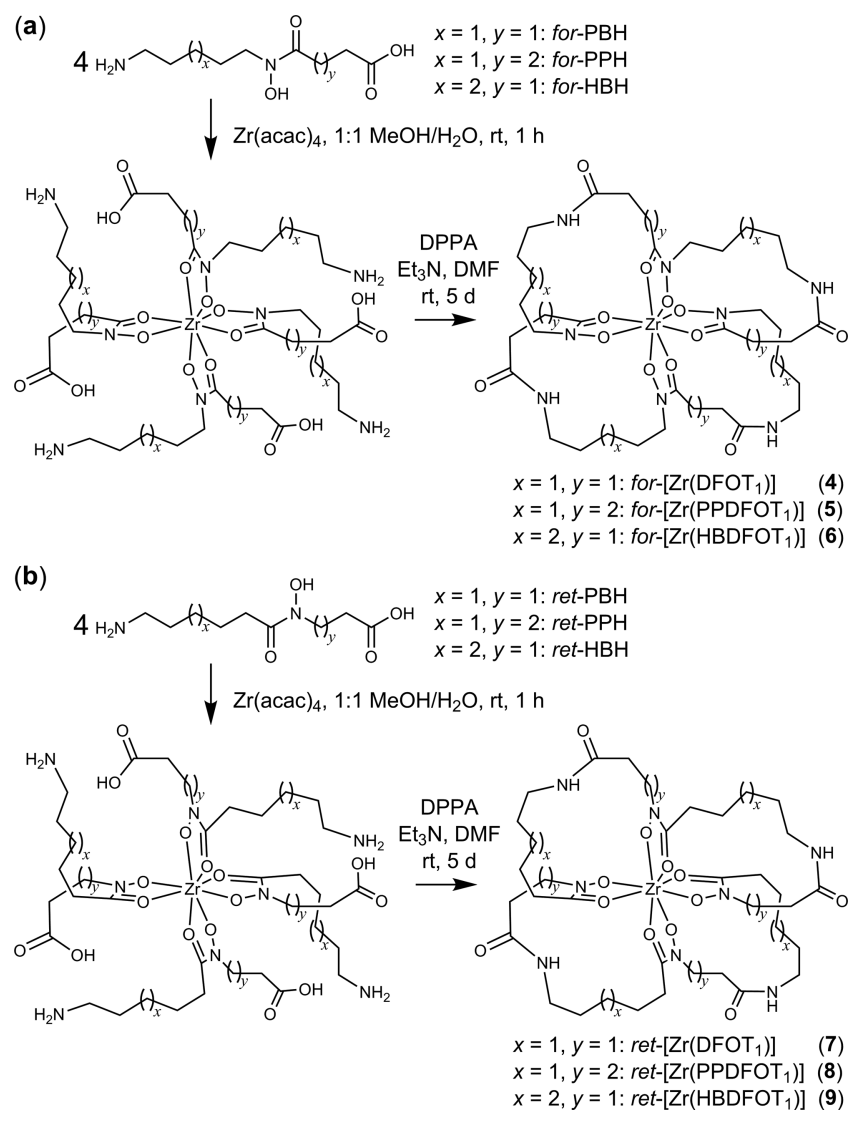

the absence of $\mathrm{Zr}(\mathrm{IV})$, which demonstrated the essential nature of the $\mathrm{Zr}(\mathrm{IV})$ ion template in the reaction.

In the $\mathrm{Zr}(\mathrm{IV})$-for-PPH MTS system (SIM 943), two wellresolved peaks were present in the $\mathrm{LC}$ at $t_{\mathrm{R}}=37.4 \mathrm{~min}$ and $t_{\mathrm{R}}=$ $42.7 \mathrm{~min}$ (Figure 1b). Each of these peaks gave experimental MS signals $\left(t_{\mathrm{R}}=42.7 \mathrm{~min}\right.$, Figure $2 \mathrm{~b} ; t_{\mathrm{R}}=37.4 \mathrm{~min}$, Figure $\left.2 \mathrm{c}\right)$ that correlated with the presence of the $[\mathrm{M}+2 \mathrm{H}]^{2+},[\mathrm{M}+\mathrm{H}]^{+}$, and $[\mathrm{M}+\mathrm{Na}]^{+}$adducts of for- $\left[\mathrm{Zr}\left(\mathrm{PPDFOT}_{1}\right)\right]$ (5) (calculated data Figure $2 \mathrm{e}-\mathrm{f})$. The presence of two peaks with identical MS characteristics was unexpected and was examined further in later experiments. The presence of four additional methylene groups in for-[ $\left.\mathrm{Zr}\left(\mathrm{PPDFOT}_{1}\right)\right]$ (5) compared to for-[ $\mathrm{Zr}$ $\left(\mathrm{DFOT}_{1}\right)$ ] (4), was consistent with the increase of $56 \mathrm{~m} / z$ units in the $[\mathrm{M}+\mathrm{H}]^{+}$adduct signal, with other adducts also showing consistent increases. Signals ascribable to the linear tetramer precursor of for $\left[\mathrm{Zr}\left(\mathrm{PPDFOT}_{1}\right)\right](5)$ or the trimeric DFOE-type macrocyclic analogue were not detected in this system, or for any other monomer.

No LC peaks were discernible from the $\mathrm{Zr}(\mathrm{IV})$-for- $\mathrm{HBH}$ (Figure 1c) or the $\mathrm{Zr}(\mathrm{IV})$-ret-HBH (Figure 1f) MTS systems (SIM 943), which suggested that the formation of for$\left[\mathrm{Zr}\left(\mathrm{HBDFOT}_{1}\right)\right]$ (6) and ret-[Zr($\left.\left(\mathrm{HBDFOT}_{1}\right)\right]$ (9) was unfavorable. The relative intensities of the LC peaks observed for the $\mathrm{Zr}(\mathrm{IV})$-ret-PBH (Figure 1d) or the $\mathrm{Zr}(\mathrm{IV}$ )-ret-PPH (Figure 1e) MTS systems to form macrocycles ret-[Zr$\left.\left(\mathrm{DFOT}_{1}\right)\right](7)$ or ret-[Zr(PPDFOT 1$\left.)\right](8)$, respectively, was less than the corresponding for-PBH or for-PPH ligand systems, which indicated for-endo-hydroxamic acid monomers were favored above the ret-monomers in the $\mathrm{Zr}(\mathrm{IV})$-macrocycle
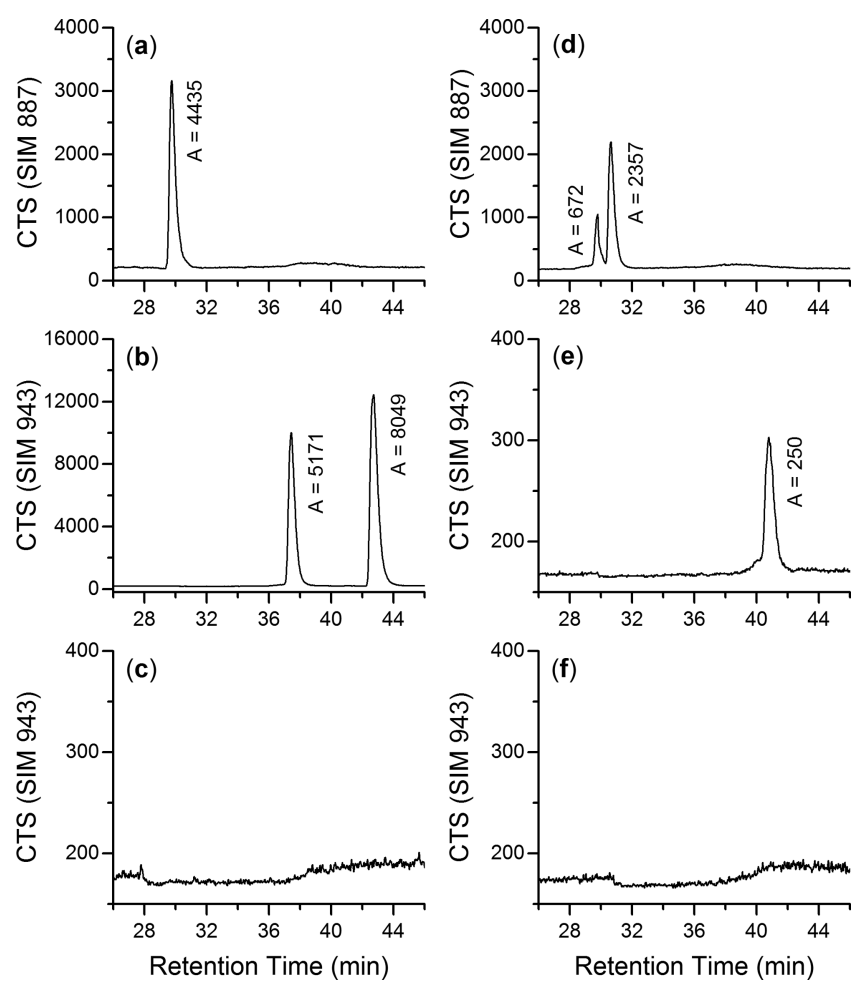

Figure 1. Liquid chromatograms from a solution of $\mathrm{Zr}(\mathrm{IV})$ and (a) for$\mathrm{PBH},(\mathrm{b})$ for- $\mathrm{PPH},(\mathrm{c})$ for- $\mathrm{HBH},(\mathrm{d})$ ret- $\mathrm{PBH},(\mathrm{e})$ ret- $\mathrm{PPH}$, or (f) ret$\mathrm{HBH}$, after reaction with peptide coupling reagents. Selected ion monitoring (SIM) was used as the detection mode, with values set to correspond with the $[\mathrm{M}+\mathrm{H}]^{+}$adduct of the cognate macrocycle 4-9.
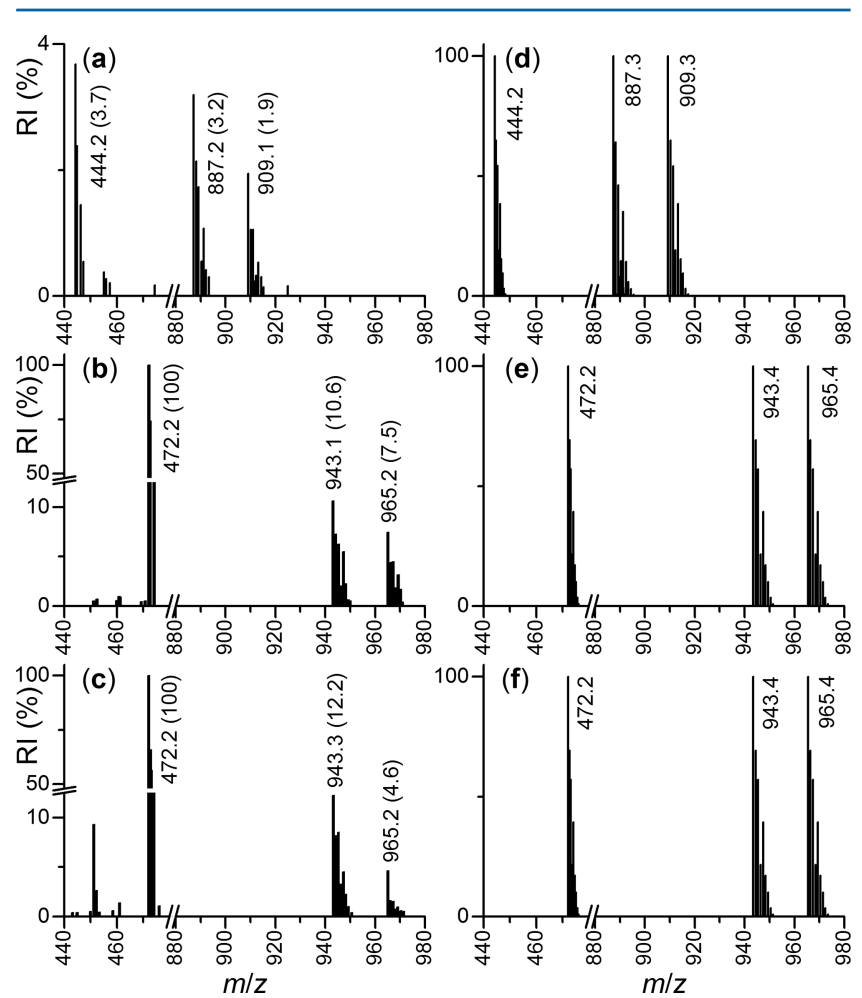

Figure 2. MS signals from the LC peaks detected using SIM values corresponding with (a) for $\left[\mathrm{Zr}\left(\mathrm{DFOT}_{1}\right)\right]$, and the two peaks consistent with for $-\left[\mathrm{Zr}\left(\mathrm{PPDFOT}_{1}\right)\right]$ at $(\mathrm{b}) t_{\mathrm{R}}=42.7 \mathrm{~min}$ and $(\mathrm{c}) t_{\mathrm{R}}$ $=37.4 \mathrm{~min}$. The calculated isotope patterns for the corresponding species are aligned at right $(\mathrm{d}-\mathrm{f})$. 
formation. The LC trace from the $\mathrm{Zr}(\mathrm{IV})$-ret-PBH MTS system was also resolved into two peaks, representing ret-[Zr$\left.\left(\mathrm{DFOT}_{1}\right)\right](7)$ and a second species of an uncertain nature. Peak integration gave a for- $\mathrm{PBH} /$ ret- $\mathrm{PBH}$ (sum of both peaks) ratio of 1.5 , and a for- $\mathrm{PPH} /$ ret-PPH (sum of both peaks) ratio of 52.9 .

Overall, the results demonstrated a degree of ligand selectivity was in operation in $\mathrm{Zr}(\mathrm{IV})$-mediated macrocycle assembly. The use of MTS for the preparation of trimeric $\mathrm{Fe}$ (III)-loaded macrocycles, ${ }^{47}$ showed a similar selectivity ratio with respect to the for- $\mathrm{PBH} /$ ret-PBH system. As distinct from the $\mathrm{Zr}(\mathrm{IV})$-based MTS system, $\mathrm{Fe}(\mathrm{III})$-loaded macrocycles were formed with for-HBH and ret-HBH, which demonstrated metal ion selectivity was in operation in the MTS systems.

Characterization of the Two Species in the $\mathrm{Zr}$ (IV)-for-

PPH MTS System. The LC peaks for the higher-yielding $\mathrm{Zr}(\mathrm{IV})$-MTS systems using for-PBH or for-PPH were collected for further characterization. The two peaks in the for-PPH system (Figure 1b) were collected separately and the integrity of the species confirmed by LC, with the species showing elution times of $t_{\mathrm{R}}=35.5 \mathrm{~min}$ (Figure $3 \mathrm{a}$ ) and $41.0 \mathrm{~min}$ (Figure $3 \mathrm{~g}$ ). The trace using TIC detection (black) was coincident with the trace (gray) using SIM values representative of for$\left[\mathrm{Zr}\left(\mathrm{PPDFOT}_{1}\right)\right](5)$. The absolute retention times were different from the first acquired LC data, which was due to instrumental variation. To better understand the nature of the species, each fraction was incubated with EDTA at $\mathrm{pH}$ 4.0, with samples analyzed by LC-MS at 24 and $60 \mathrm{~h}$. After $24 \mathrm{~h}$, the earlier-eluting species gave a new signal using TIC detection at $t_{\mathrm{R}}=28.1 \mathrm{~min}$ (Figure $3 \mathrm{~b}$ ), which gave an experimental MS isotope pattern (Figure $3 \mathrm{e}$ ) consistent with the calculated pattern (Figure 3f) of $[\mathrm{M}+2 \mathrm{H}]^{2+},[\mathrm{M}+\mathrm{H}]^{+}$and $[\mathrm{M}+\mathrm{Na}]^{+}$ adducts of a $\mathrm{Zr}(\mathrm{IV})$-free dimeric hydroxamic acid macrocycle assembled from two for-PPH units. After $60 \mathrm{~h}$, the dimeric hydroxamic acid macrocycle remained present (Figure 3c, gray) with no remaining trace of the $\mathrm{Zr}$ (IV)-loaded parent species (Figure 3c, black). This supported that the earlier-eluting $\mathrm{Zr}(\mathrm{IV})$ species at $t_{\mathrm{R}}=35.5 \mathrm{~min}$ was a complex of $\mathrm{Zr}(\mathrm{IV})$, in which the coordination sphere was saturated by two tetradentate dimeric macrocycles: for-[ $\left.\mathrm{Zr}\left(\mathrm{PPDFOT}_{1 \mathrm{D}}\right)_{2}\right]$ (Scheme 2, 10). The complex for- $\left[\mathrm{Zr}\left(\mathrm{PPDFOT}_{1 \mathrm{D}}\right)_{2}\right]$ (10) was an isomer of for-[ $\left.\mathrm{Zr}\left(\operatorname{PPDFOT}_{1}\right)\right](5)$, in which the coordination sphere of the latter was saturated by one octadentate tetrameric macrocycle.

The dimeric macrocycle $\mathbf{1 1}$ released from EDTA-treated $\mathbf{1 0}$ is an analogue of the small family of dimeric hydroxamic acid macrocycles identified as natural bacterial siderophores, including alcaligin, ${ }^{55}$ bisucaberin, ${ }^{56}$ putrebactin, ${ }^{57}$ and avaroferrin. ${ }^{58-60}$ Since for-PPH contains one extra methylene group than for-PBH, which is the native monomer of the symmetric dimer bisucaberin, macrocycle $\mathbf{1 1}$ has been given the common name homobisucaberin (HBC).

After $24 \mathrm{~h}$ incubation with EDTA, the later-eluting $\mathrm{Zr}$ (IV) species gave a signal using TIC detection at $t_{\mathrm{R}}=36.7 \mathrm{~min}$ (Figure $3 \mathrm{~h}$ ), with an experimental MS isotope pattern (Figure $3 \mathrm{k})$ consistent with the calculated pattern of $[\mathrm{M}+2 \mathrm{H}]^{2+},[\mathrm{M}+$ $\mathrm{H}+\mathrm{Na}]^{2+},[\mathrm{M}+\mathrm{H}+\mathrm{K}]^{2+},[\mathrm{M}+\mathrm{H}]^{+}$, and $[\mathrm{M}+\mathrm{Na}]^{+}$adducts (Figure 31) of the apo-macrocycle PPDFOT 1 (12). There was a trace of for $-\left[\mathrm{Zr}\left(\mathrm{PPDFOT}_{1 \mathrm{D}}\right)_{2}\right](\mathbf{1 0})$ in this solution, which gave rise to a low intensity MS signal at $\mathrm{m} / z 451.2$. After $60 \mathrm{~h}$ incubation, there remained traces of the parent for- $[\mathrm{Zr}$ $\left.\left(\mathrm{PPDFOT}_{1}\right)\right](5)$ (Figure 3i, black) in addition to the apomacrocycle (gray). This demonstrated that the $\mathrm{Zr}(\mathrm{IV})$ ion was
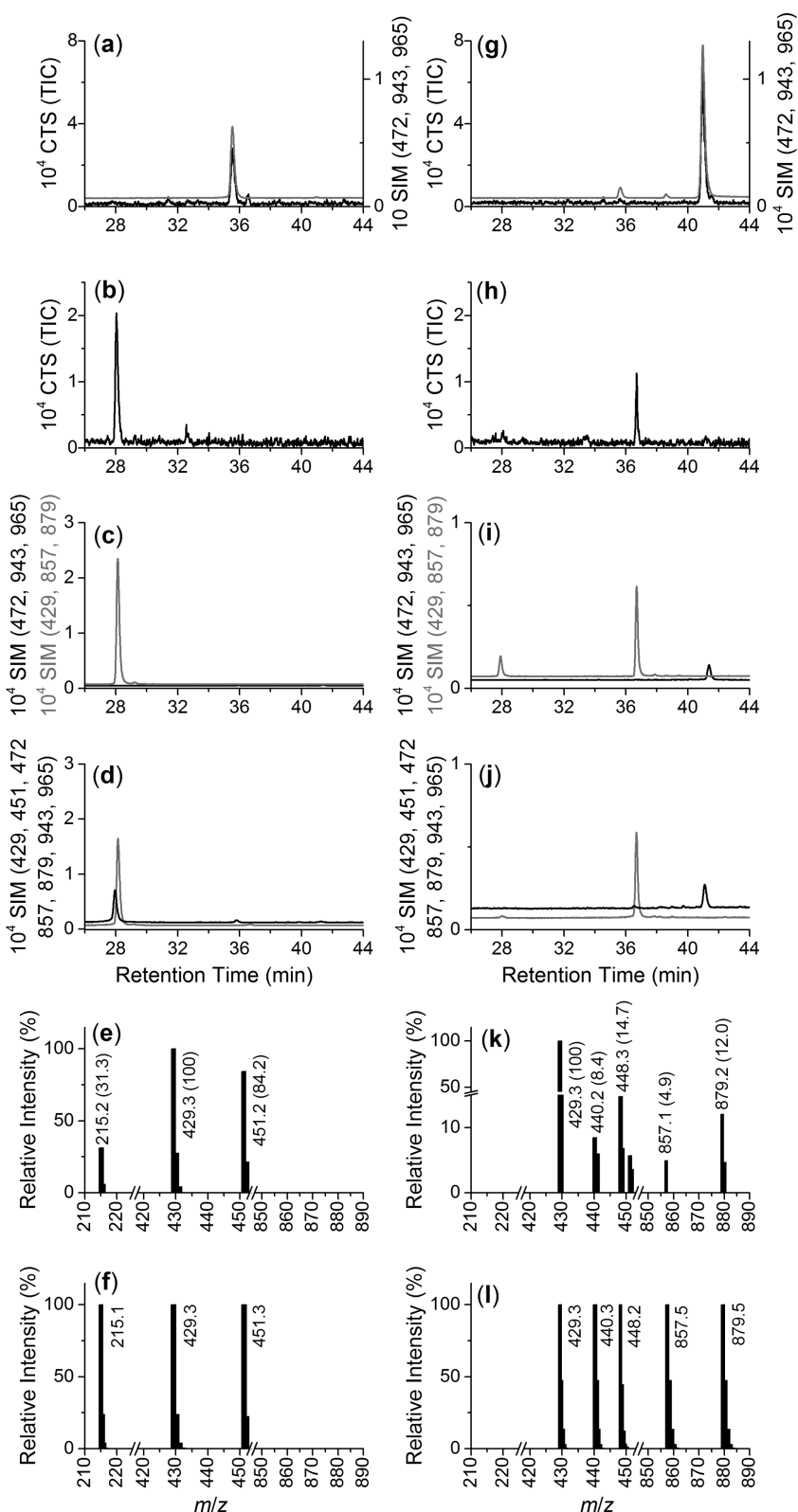

Figure 3. LC-MS data from a solution of $\mathbf{1 0}$ (column at left) or $\mathbf{5}$ (column at right), detected as (a, g) TIC (black) or at SIM values (gray) 472, 943, 965, corresponding to 5 and 10, and following incubation with EDTA ( $\mathrm{pH} 4$ ), detected as (b, h) TIC, or (c, (i) SIM values (black) 472, 943, 965, corresponding to 5 and 10, or SIM values (gray) 429, 857, 879, corresponding to 11 and 12, or after incubation of the peak at (d) $28.1 \mathrm{~min}$ (gray) or (j) $36.7 \mathrm{~min}$ (gray) with $\mathrm{Zr}$ (IV), detected as (d, j) SIM values (black) 429, 451, 472, 857, 879, 943, 965, corresponding with 5 and 10 and 11 and 12. The MS signal from the peak at $28.1 \mathrm{~min}$ attributable to $\mathbf{1 1}$ is shown as experiment (e) or calculated (f); or at $36.7 \mathrm{~min}$ attributable to 12 as experiment (k) or calculated (1).

more readily removed from for- $\left[\mathrm{Zr}\left(\mathrm{PPDFOT}_{1 \mathrm{D}}\right)_{2}\right]$ (10) than for- $\left[\mathrm{Zr}\left(\mathrm{PPDFOT}_{1}\right)\right](5)$. The extraction of $\mathrm{Zr}(\mathrm{IV})$ was $\mathrm{pH}$ dependent, with negligible $\mathrm{Zr}(\mathrm{IV})$ removed from for-[Zr$\left.\left(\mathrm{PPDFOT}_{1}\right)\right](5)$ at $\mathrm{pH}$ 7.0. An ${ }^{1} \mathrm{H}$ NMR spectrum of for$\left[\mathrm{Zr}\left(\mathrm{PPDFOT}_{1}\right)\right](5)$ (Figure S8) showed signals that were clustered in regions similar to those observed for a $\mathrm{Zr}(\mathrm{IV})$ DFOB complex, ${ }^{39}$ although the signal complexity from conformational flux prevented the unambiguous assignment. 
Scheme 2. $\mathrm{Zr}$ (IV):for-PPH Complexes (1:4) Preorganized to Form for-[Zr(PPDFOT 1$)]$ (5) or for-[ $\left.\mathrm{Zr}\left(\mathrm{PPDFOT}_{1 \mathrm{D}}\right)_{2}\right]$ $(10)^{a}$
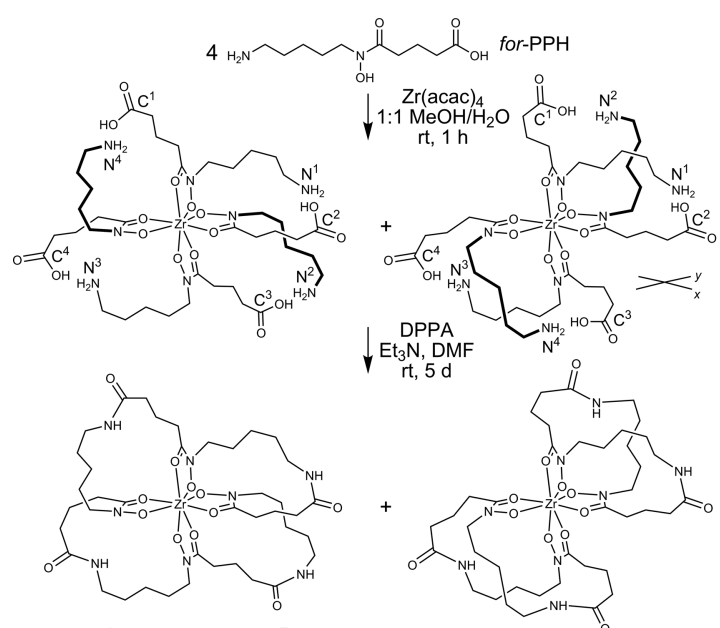

for-[Zr(PPDFOT 1$)](5)$
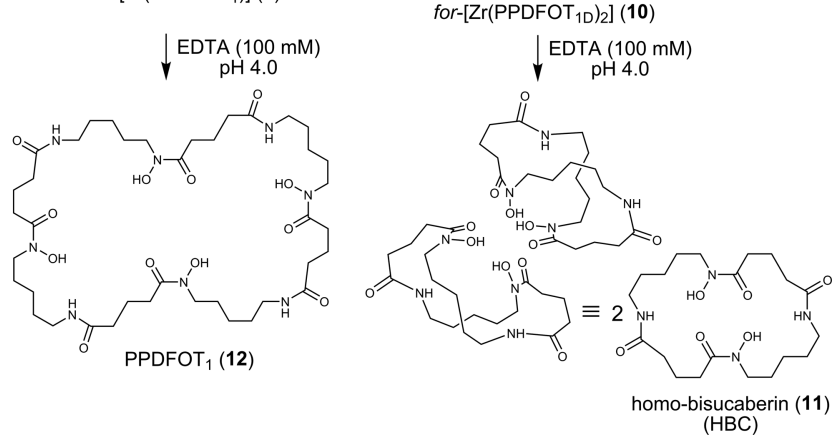

${ }^{a}$ Demetallation of 10 gave homo-bisucaberin 11, and demetallation of 5 gave 12 in analytical yields.

The apo-macrocycles $\mathbf{1 1}$ and $\mathbf{1 2}$ were isolated and incubated with $\mathrm{Zr}(\mathrm{IV})$ to examine the reincorporation of $\mathrm{Zr}(\mathrm{IV})$, as a surrogate of the radiolabeling procedure. Incubation for $1 \mathrm{~h}$ of the dimeric hydroxamic acid macrocycle 11 with $\mathrm{Zr}(\mathrm{IV})$ did not reassemble for- $\left[\mathrm{Zr}\left(\mathrm{PPDFOT}_{1 \mathrm{D}}\right)_{2}\right](\mathbf{1 0})$, with the traces for the free ligand (Figure 3d, gray) and the solution following $\mathrm{Zr}(\mathrm{IV}$ ) incubation (Figure 3d, black) coincident. Incubation of the tetrameric hydroxamic apo-macrocycle $\operatorname{PPDFOT}_{1}(12)$ (Figure $3 \mathbf{j}$, gray) with $\mathrm{Zr}(\mathrm{IV})$ showed a signal (Figure 3j, black) that was coincident with for-[ $\left.\mathrm{Zr}\left(\mathrm{PPDFOT}_{1}\right)\right](\mathbf{5})$, which supported the viability of radiolabeling these types of macrocycles.

A repeat MTS reaction between $\mathrm{Zr}(\mathrm{IV})$ and for-PPH gave an LC trace with a similar distribution of $\left[\mathrm{Zr}\left(\mathrm{PPDFOT}_{1}\right)\right](5)$ and for $-\left[\mathrm{Zr}\left(\mathrm{PPDFOT}_{1 \mathrm{D}}\right)_{2}\right]$ (10) (Figure S9) as first observed, supporting the reproducibility of the system. Each peak was isolated and a subsample subject to EDTA-based $\mathrm{Zr}(\mathrm{IV})$ removal ( $\mathrm{pH}$ 4.0) and purification to give a sample set of the $\mathrm{Zr}(\mathrm{IV})$-loaded macrocycles ([Zr $\left.\left(\mathrm{PPDFOT}_{1}\right)\right]$ (5), for-[Zr$\left.\left.\left(\mathrm{PPDFOT}_{1 \mathrm{D}}\right)_{2}\right](\mathbf{1 0})\right)$, and the corresponding apo-macrocycles (PPDFOT 1 (12), and $\mathrm{HBC}$ (11)) for analysis by high resolution MS. Each species analyzed in the HRMS as the $[\mathrm{M}+\mathrm{Na}]^{+}$adduct, with $\mathrm{HBC}(\mathbf{1 1})$ showing an additional adduct $[\mathrm{M}]^{+}$attributable to a complex formed with adventitious $\mathrm{Al}^{3+}$ (Figure S10-S13).

The formation of for $\left[\mathrm{Zr}\left(\mathrm{PPDFOT}_{1}\right)\right]$ (5) would require coupling between the amine group of monomer $1\left(\mathrm{~N}^{1}\right)$ and the DPPA-activated carboxylic acid group of monomer $2\left(\mathrm{C}^{2}\right)$; and contiguous coupling between $\mathrm{N}^{2}$ and $\mathrm{C}^{3}, \mathrm{~N}^{3}$ and $\mathrm{C}^{4}$, and $\mathrm{N}^{4}$ and $\mathrm{C}^{1}$ (Scheme 2). As similar to for-[Zr(PPDFOT 1 ) $]$ (5), the formation of for- $\left[\mathrm{Zr}\left(\mathrm{PPDFOT}_{1 \mathrm{D}}\right)_{2}\right]$ (10) would require coupling between $\mathrm{N}^{1}$ and $\mathrm{C}^{2}$, but a second coupling between $\mathrm{C}^{1}$ and $\mathrm{N}^{2}$. The $\mathrm{C}^{1}-\mathrm{N}^{2}$ coupling would require the pendent amine group of monomer 2 to reorient from below the $x-y$ plane to above the $x-y$ plane. The other dimeric macrocycle comprising for-[ $\left.\mathrm{Zr}\left(\mathrm{PPDFOT}_{1 \mathrm{D}}\right)_{2}\right]$ would be formed upon coupling between $\mathrm{N}^{3}$ and $\mathrm{C}^{4}$, as common to for-[ $\mathrm{Zr}$ $\left(\mathrm{PPDFOT}_{1}\right)$, and between $\mathrm{C}^{3}$ and $\mathrm{N}^{4}$, requiring the pendent amine group of monomer 4 move below the $x-y$ plane (Scheme 2 ). In the case of the for-PPH MTS system, the distribution of both conformers as determined by probability, and the proximity of the relevant amine and activated carboxylic acid termini, were favorably poised to promote the formation of for$\left[\mathrm{Zr}\left(\mathrm{PPDFOT}_{1}\right)\right](\mathbf{5})$ and for $-\left[\mathrm{Zr}\left(\mathrm{PPDFOT}_{1 \mathrm{D}}\right)_{2}\right]$ (10). LC-MS analysis of the bulk solution from the ret-PBH MTS system following incubation with EDTA at $\mathrm{pH} 4.0$ supported the presence of ret-[Zr(DFOT 1$)](7)$ and ret-[Zr(DFOT $\left.\left.{ }_{1 \mathrm{D}}\right)_{2}\right]$.

Molecular Mechanics Calculations. Structures of the $\mathrm{Zr}$ (IV) complexes with for-PBH, for-PPH or for-HBH to form a 1:1 $\mathrm{Zr}(\mathrm{IV})$ :tetrameric macrocycle or a $1: 2 \mathrm{Zr}(\mathrm{IV})$ :dimeric macrocycle were built using $\mathrm{X}$-ray crystallographic data for $\left[\mathrm{Zr}(\mathrm{Me}-\mathrm{AHA})_{4}\right]$ (Me-AHAH $=\mathrm{N}$-methylacetohydroxamic acid ${ }^{15}$ as the core of the molecule, and fragments of for$\mathrm{PBH}$ from the structure of $[\mathrm{Fe}(\mathrm{DFOB})]$ (Figure 4). ${ }^{61}$ Molecular mechanics calculations showed that from the six complexes, for-[ $\left.\mathrm{Zr}\left(\mathrm{DFOT}_{1}\right)\right](4)$ gave the highest value for the minimum energy (Table 1), which was attributed to ring strain imposed by the suboptimal chain length of the for- $\mathrm{PBH}$ ligand. The average of the torsion angle of the four amide bonds was used as a surrogate measure of ring strain, with the value for for$\left[\mathrm{Zr}\left(\mathrm{DFOT}_{1}\right)\right]$ deviating the most from $180^{\circ}$. There was a significant decrease in the energy minimum for for-[Zr$\left.\left(\mathrm{DFOT}_{1 \mathrm{D}}\right)_{2}\right]$, which was attributed to the reduction in the ring strain from for-[Zr(DFOT 1$)]$ to the isomer for-[Zr$\left.\left(\mathrm{DFOT}_{1 \mathrm{D}}\right)_{2}\right]$. In each isomer pair of the $1: 1 \mathrm{Zr}(\mathrm{IV})$ :tetrameric macrocycle and the 1:2 $\mathrm{Zr}(\mathrm{IV})$ :dimeric macrocycle, the latter isomer gave a lower energy minimum, consistent with the notion that the organization of dimers reduced the ring strain in the octadentate complex. Molecular mechanics calculations using an alternative model of the $\mathrm{Zr}$ (IV) coordination sphere ${ }^{42}$ gave high-energy structures of the dimer complexes, with one wing of the dimer partially inserted into the other, which supported the veracity of using the $\left[\mathrm{Zr}(\mathrm{Me}-\mathrm{AHA})_{4}\right]$ core in the modeling.

As expected, the complexes modeled with for-PPH and for$\mathrm{HBH}$, that contained one additional methylene group than for$\mathrm{PBH}$, had greater volumes than for-[Zr(DFOT $\left.\left.{ }_{1}\right)\right]$ and for$\left[\mathrm{Zr}\left(\mathrm{DFOT}_{1 \mathrm{D}}\right)_{2}\right]$. The energy minimum for for-[ $\mathrm{Zr}$ $\left.\left(\mathrm{PPDFOT}_{1}\right)\right](\mathbf{5})$ was significantly less than for-[Zr(DFOT $\left.\left.{ }_{1}\right)\right]$ (4), which indicated that the additional methylene group in for$\mathrm{PPH}$ was beneficial in the formation of a tetrameric macrocycle with a cavity size better optimized for the accommodation of the $\mathrm{Zr}(\mathrm{IV})$ ion. The reduced energy minimum for for$\left[\mathrm{Zr}\left(\mathrm{PPDFOT}_{1}\right)\right]$ (48 main-chain atoms) than for-[Zr$\left.\left(\mathrm{DFOT}_{1}\right)\right]$ (44 main-chain atoms) could be considered more amplified than the absolute value, based on calibration to the number of main-chain atoms in the macrocycle, giving 11.6 or $14 \mathrm{kcal} / \mathrm{mol}$ per main-chain atom, respectively.

The structures of for- $\left[\mathrm{Zr}\left(\mathrm{PPDFOT}_{1}\right)\right]$ and for-[Zr$\left.\left(\mathrm{PPDFOT}_{1 \mathrm{D}}\right)_{2}\right]$ showed the amide oxygen atom was oriented away from the $\mathrm{Zr}(\mathrm{IV})-\mathrm{O}_{8}$ coordination sphere, with an average distance (as measured from each amide oxygen atom to the 
a

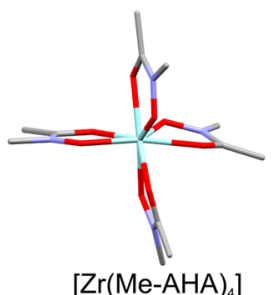

$\mathrm{b}$
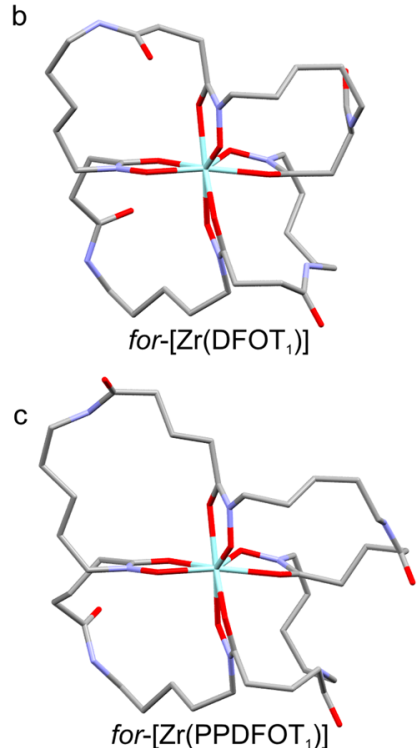

d

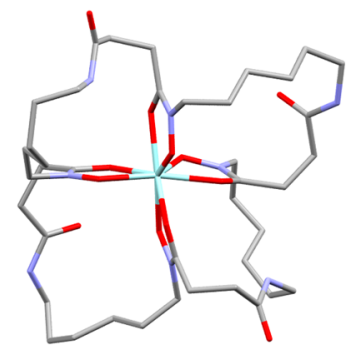

for-[Zr(HBDFOT $\left.\left.)_{1}\right)\right]$
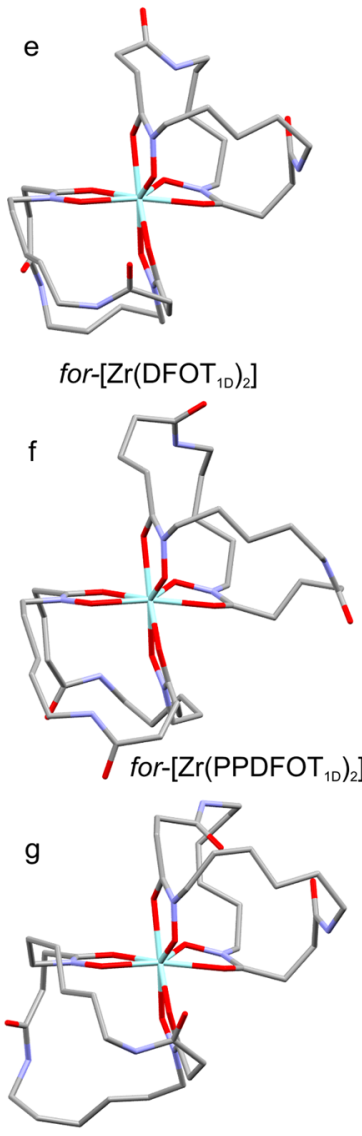

for- $\left[\mathrm{Zr}\left(\mathrm{HBDFOT}_{10}\right)_{2}\right]$

Figure 4. Structures of (a) $\mathrm{Zr}(\mathrm{IV})-(\mathrm{Me}-\mathrm{AHA})_{4}$ from $\mathrm{X}$-ray crystallography $^{15}$ or from molecular mechanics calculations of the complex between $\mathrm{Zr}(\mathrm{IV})$ and a tetrameric macrocycle ( $\mathrm{Zr}(\mathrm{IV})$ :ligand $1: 1)$ or the cognate dimeric macrocycle ( $\mathrm{Zr}(\mathrm{IV})$ :ligand 1:2) assembled from (b, e) for $-\mathrm{PBH},(\mathrm{c}, \mathrm{f})$ for- $\mathrm{PPH}$, or (d, g) for- $\mathrm{HBH}$.

Table 1. Data from Molecular Mechanics Calculations of the Zr(IV)-Loaded Macrocycles

\begin{tabular}{|c|c|c|c|c|c|}
\hline \multirow[b]{2}{*}{ complex } & \multirow[b]{2}{*}{$\begin{array}{c}\text { energy } \\
(\mathrm{kcal} / \mathrm{mol})\end{array}$} & \multirow[b]{2}{*}{$\begin{array}{l}\text { vol. } \\
\left(\AA^{3}\right)\end{array}$} & \multirow[b]{2}{*}{$\begin{array}{l}\theta_{\text {amide }} \\
(\mathrm{deg})\end{array}$} & \multicolumn{2}{|c|}{$\begin{array}{l}\text { distance } \mathrm{C}_{\mathrm{O}_{\text {amide }}}- \\
\mathrm{C} \underline{\mathrm{O}} / \mathrm{N} \underline{\mathrm{O}}_{\mathrm{HX}}(\hat{\AA})\end{array}$} \\
\hline & & & & $\begin{array}{c}\text { av } \\
(n=16)\end{array}$ & $\min$ \\
\hline for $-\left[\mathrm{Zr}\left(\mathrm{DFOT}_{1}\right)\right]$ & 563 & 1928 & 176.7 & 4.971 & 3.033 \\
\hline for $-\left[\mathrm{Zr}\left(\mathrm{DFOT}_{1 \mathrm{D}}\right)_{2}\right]$ & 544 & 1961 & 177.7 & 5.141 & 3.572 \\
\hline for- $\left[\mathrm{Zr}\left(\mathrm{PPDFOT}_{1}\right)\right]$ & 555 & 2113 & 178.2 & 6.478 & 4.756 \\
\hline $\begin{array}{l}\text { for- } \\
\qquad\left[\mathrm{Zr}\left(\mathrm{PPDFOT}_{1 \mathrm{D}}\right)_{2}\right]\end{array}$ & 543 & 2173 & 178.2 & 6.346 & 4.859 \\
\hline for $-\left[\mathrm{Zr}\left(\mathrm{HBDFOT}_{1}\right)\right]$ & 552 & 2102 & 178.1 & 5.176 & 3.087 \\
\hline $\begin{array}{l}\text { for- } \\
\qquad\left[\mathrm{Zr}\left(\mathrm{HBDFOT}_{1 \mathrm{D}}\right)_{2}\right]\end{array}$ & 551 & 2117 & 177.5 & 4.829 & 2.922 \\
\hline
\end{tabular}

four oxygen donor atoms in the relevant quadrant) > $6.3 \AA$, with the minimum distance of about $4.7 \AA$. In the case of for$\left[\mathrm{Zr}\left(\mathrm{DFOT}_{1}\right)\right]$ and for $-\left[\mathrm{Zr}\left(\mathrm{DFOT}_{1 \mathrm{D}}\right)_{2}\right]$ or for- $\left[\mathrm{Zr}\left(\mathrm{HBDFOT}_{1}\right)\right]$ and for- $\left[\mathrm{Zr}\left(\mathrm{HBDFOT}_{1 \mathrm{D}}\right)_{2}\right]$, there appeared to be a greater

degree of steric and electronic repulsion resulting from the proximity of the amide oxygen atoms to the $\mathrm{Zr}(\mathrm{IV})-\mathrm{O}_{8}$ coordination sphere. These effects provide a possible rationale for the preference of the for-PPH ligand in the macrocycle assembly, and the lower concentration or no complex formation in the for- $\mathrm{PBH}$ and for- $\mathrm{HBH}$ ligand systems, respectively.

Release of $\mathrm{Zr}(\mathrm{IV})$ with EDTA Treatment. It was posited that in the presence of EDTA at physiological $\mathrm{pH}$ values, the $\mathrm{Zr}(\mathrm{IV})$ ion would be better retained by the $\mathrm{Zr}$ (IV)-loaded macrocycles, compared to related linear ligands. In the presence of a significant excess of EDTA, $\mathrm{Zr}(\mathrm{IV})$ was completely removed at $\mathrm{pH} 7.0$ from $\left[\mathrm{Zr}(\mathrm{DFOB})\left(\mathrm{OH}_{2}\right)_{2}\right]^{+}(2)$ after $1 \mathrm{~h}$ incubation time (Figure 5). About $60 \%$ of $\mathrm{Zr}(\mathrm{IV})$ was retained

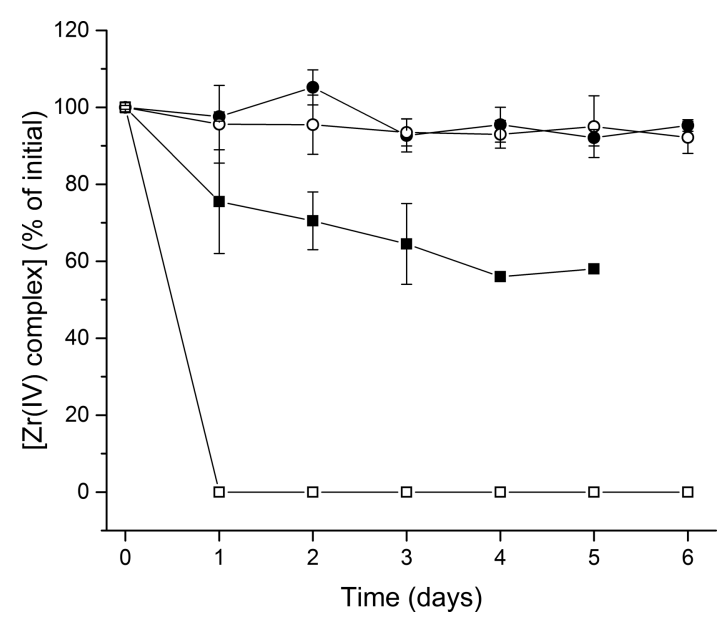

Figure 5. Percentage $(n=3)$ of initial concentration (LC-MS, SIM detection of the $[\mathrm{M}]^{+}$or $[\mathrm{M}+\mathrm{H}]^{+}$adduct) of $[\mathrm{Zr}(\mathrm{DFOB})]^{+}$(open square), $[\mathrm{Zr}(\mathrm{DFOB}-$ for-PBH)] (closed square; $n=1$ for $t=4,5 \mathrm{~d}$ ), for $-\left[\mathrm{Zr}\left(\mathrm{DFOT}_{1}\right)\right]$ (open circle) or for $-\left[\mathrm{Zr}\left(\mathrm{PPDFOT}_{1}\right)\right]$ (closed circle) at $t=0,1-6$ days, in the presence of 1800 equiv of EDTA at $\mathrm{pH} 7.0$.

in the linear, tetrameric chain-extended DFOB analogue [Zr(DFOB-for-PBH) $]$ (3) after $72 \mathrm{~h}$ (refer to the ESI for the synthesis of DFOB-for-PBH, Figure S14). The trend in the increased stability of $[\mathrm{Zr}(\mathrm{DFOB}-$ for-PBH $)]$ (3) above [Zr(DFOB) $\left.\left(\mathrm{OH}_{2}\right)_{2}\right]^{+}(2)$ due to the increased ligand denticity was in agreement with previous work. ${ }^{32}$ The current work showed a greater loss of $\mathrm{Zr}(\mathrm{IV})$ from [ $\mathrm{Zr}(\mathrm{DFOB}-$ for $-\mathrm{PBH})$ ] (3), which was ascribed to differences in reaction conditions and/or the use of a significant excess of EDTA, as was necessary for nonradioactive methods of detection. The loss of $\mathrm{Zr}(\mathrm{IV})$ from for-[Zr(DFOT 1$)](4)$ or for-[Zr(PPDFOT 1 ) $]$ (5) was minimal under the same conditions, with $93 \%$ or $96 \%$ of the respective $\mathrm{Zr}(\mathrm{IV})$-loaded macrocycles detected after $72 \mathrm{~h}$. The minimal loss of $\mathrm{Zr}(\mathrm{IV})$ from for-[Zr(DFOT $\left.\left.{ }_{1}\right)\right]$ (4) and for$\left[\mathrm{Zr}\left(\mathrm{PPDFOT}_{1}\right)\right](5)$ at $\mathrm{pH} 7.0$ indicates the value that these types of macrocycles could have in $\mathrm{Zr}(\mathrm{IV})-89$ PET imaging applications, to attenuate the loss of the $\mathrm{Zr}(\mathrm{IV})-89$ radiolabel in vivo. The stability of the 44- or 48-membered macrocycles, for$\left[\mathrm{Zr}\left(\mathrm{DFOT}_{1}\right)\right]$ (4) or for- $\left[\mathrm{Zr}\left(\mathrm{PPDFOT}_{1}\right)\right]$ (5), respectively, was in accord with previously reported $\mathrm{Zr}(\mathrm{IV})$ macrocycles. ${ }^{42,43}$

\section{CONCLUSION}

Reaction between $\mathrm{Zr}(\mathrm{IV})$ and a selection of endo-hydroxamic acid amino carboxylic acid ligands in a 1:4 stoichiometry in the presence of peptide coupling reagents was used to prepare $\mathrm{Zr}(\mathrm{IV})$-loaded macrocycles. Of the six hydroxamic acid 
monomers examined using this MTS approach, for-PPH gave the highest concentration of $\mathrm{Zr}(\mathrm{IV})$-loaded macrocycle, which was produced as an octadentate tetramer: for-[ $\left.\mathrm{Zr}\left(\mathrm{PPDFOT}_{1}\right)\right]$ (5). An unexpected product was an octadentate $\mathrm{Zr}(\mathrm{IV})$-loaded complex formed with two for-PPH derived dimeric macrocycles: for $\left[\mathrm{Zr}\left(\mathrm{PPDFOT}_{1 \mathrm{D}}\right)_{2}\right](\mathbf{1 0})$. These two complexes are isomers. The MTS-based synthesis of for-[Zr(PPDFOT 1$)]$ (5) was facile, albeit with the product formed in a modest yield (about 11\%). MTS may have most value in identifying the ideal monomer required for the assembly of the optimal macrocycle, with more conventional synthetic methods, ${ }^{62,63}$ including metal-ion-assisted ring closure, ${ }^{64}$ required to obtain more material. MTS also has value in revealing new coordination chemistry for lesser known metal ions. The apo-macrocycles $\mathrm{PPDFOT}_{1}$ (12) or homobisucaberin (HBC) (11) were obtained from the treatment of the respective compounds for- $\left[\mathrm{Zr}\left(\mathrm{PPDFOT}_{1}\right)\right](\mathbf{5})$ or for- $\left[\mathrm{Zr}\left(\mathrm{PPDFOT}_{1 \mathrm{D}}\right)_{2}\right]$ (10) with EDTA at $\mathrm{pH}$ 4.0. Incubation of $\mathrm{PPDFOT}_{1}$ with $\mathrm{Zr}(\mathrm{IV})$ for $1 \mathrm{~h}$ produced for- $\left[\mathrm{Zr}\left(\mathrm{PPDFOT}_{1}\right)\right](5)$. At $\mathrm{pH}$ values closer to physiological values, for-[Zr(DFOT 1$)]$ (4) and for-[Zr$\left.\left(\mathrm{PPDFOT}_{1}\right)\right]$ (5) were stable toward the loss of $\mathrm{Zr}(\mathrm{IV})$, with the metal ion leached more readily from compounds containing linear hydroxamic acid-based ligands. The design of chelators that have high affinity and selectivity toward a given radionuclide is a field that is strongly coupled to the efficacy and clinical value of PET imaging. ${ }^{1-4}$ The use of MTS to interrogate the coordination preferences of a given metal ion in the presence of a selection of fragment ligands, could have untapped potential in this regard. We are currently using MTS to inform optimal ligand design of a selection of frontier radionuclides, including Lu-177 and others.

\section{EXPERIMENTAL SECTION}

Reagents. The following chemicals were obtained from SigmaAldrich: ethyl 4-bromobutyrate (95\%), O-benzylhydroxylamine hydrochloride (99\%), Dowex $1 \times 8$ ( $\mathrm{Cl}$ form), dimethyl sulfoxide (99.9\%), diphenyl phosphoryl azide (97\%), di-tert-butyl dicarbonate $\left(\mathrm{Boc}_{2} \mathrm{O}\right.$; $\geq 98 \%$ ), tert-butyl acrylate (98\%), 1,5-dibromopentane (99\%), potassium phthalimide (97\%), triethylamine (TEA; 99\%), N,Ndimethylformamide (DMF; 99.8\%), $10 \%$ palladium on carbon, $\mathrm{N}, \mathrm{N}$ ethyldiisopropylamine (DIPEA; 99\%), tert-butanol ( $\geq 99.0 \%)$, 1,4dioxane (99.8\%), tetrahydrofuran (THF; 99.8\%), benzylchloroformate (95\%), trifluoroacetic acid (TFA; $\geq 98 \%$ ), sodium carbonate (99\%), sodium hydride (60\% suspension in oil), pyridine (99\%), succinic anhydride $(\geq 97 \%)$, glutaric anhydride $(99 \%)$, 6-aminohexanoic acid (95\%), 7-aminoheptanoic acid (98\%), and magnesium sulfate $\left(\mathrm{MgSO}_{4} ; 97 \%\right)$. Sodium sulfate $\left(\mathrm{NaSO}_{4}\right)$ and sodium bicarbonate (99.5\%) were obtained from Chemsupply. Hydrazine hydrate $\left(\mathrm{N}_{2} \mathrm{H}_{4}\right.$. $\left.\mathrm{H}_{2} \mathrm{O} ; 45-55 \%\right)$ was obtained from Ajax Chemicals. $\mathrm{N}$-[3-(dimethylamino)propyl]- $N^{\prime}$-ethylcarbodiimide hydrochloride (EDC $\cdot \mathrm{HCl} ; \geq$ $98 \%), N$-hydroxybenzotriazole (HOBt; $\geq 99 \%)$, and $N$-[(dimethylamino)-1H-1,2,3-triazolo-[4,5- $b$ ]pyridin-1-ylmethylene]- $N$-methylmethanaminium hexafluorophosphate $N$-oxide (HATU, 97\%) were obtained from ChemImpex. Hydrogen $\left(\mathrm{H}_{2}\right)$ and nitrogen $\left(\mathrm{N}_{2}\right)$ gases were sourced from BOC. All chemicals were used as received. Milli-Q water was used for all experiments.

${ }^{1} \mathrm{H}$ NMR and ${ }^{13} \mathrm{C}$ NMR Spectroscopy. ${ }^{1} \mathrm{H}$ NMR and ${ }^{13} \mathrm{C}$ NMR spectroscopy was carried out using a Varian 400-MR NMR spectrometer (Lexington, MA) at a frequency of $399.73 \mathrm{MHz}$ at 24 ${ }^{\circ} \mathrm{C}$ operated with VnmrJ 3.1 software (Agilent Technologies, Santa Clara, CA). The spectral data are reported in ppm $(\delta)$ relative to their residual solvent peaks for $\mathrm{CDCl}_{3}\left(7.27 \mathrm{ppm}\left({ }^{1} \mathrm{H}\right), 77.23 \mathrm{ppm}\left({ }^{13} \mathrm{C}\right)\right)$ or $\mathrm{CD}_{3} \mathrm{OD}\left(3.31 \mathrm{ppm}, 4.87 \mathrm{ppm}\left({ }^{1} \mathrm{H}\right), 49.00 \mathrm{ppm}\left({ }^{13} \mathrm{C}\right)\right)$ or DMSO$d_{6}\left(2.50 \mathrm{ppm}\left({ }^{1} \mathrm{H}\right), 39.52 \mathrm{ppm}\left({ }^{13} \mathrm{C}\right)\right)$. Coupling constants $(J)$ are reported in $\mathrm{Hz}$ and splitting are reported as singlet $(\mathrm{s})$, doublet $(\mathrm{d}), \mathrm{t}$ (triplet), q (quartet), and qn (quintet).
Liquid Chromatography-Mass Spectrometry. Reverse-phase LC-MS was performed using an Agilent Technologies system (Santa Clara, CA), consisting of an injector (100 $\mu \mathrm{L}$ loop), Agilent 1260 Infinity degasser, a binary pump, a fraction collector, a diode array detector and an Agilent 6120 Series Quadrupole electrospray ionization (ESI)-mass spectrometer. An Agilent C18 column reversephased prepacked column (particle size: $5 \mu \mathrm{m} ; 4.6 \times 150 \mathrm{~mm}$ internal diameter) was used at flow rate of $0.5 \mathrm{~mL} \mathrm{~min}{ }^{-1}$. Agilent OpenLAB Chromatography Data System (CDS) ChemStation Edition was used to process mass chromatograms in both the scan mode and the selected ion monitoring (SIM) mode. Two different gradients were used, as follows (A, $\mathrm{H}_{2} \mathrm{O}$ /formic acid 99.9:0.1; B, ACN/formic acid 99.9:0.1). Method A: 0-42\% B over $60 \mathrm{~min}$ (Figure 1, Figure 3, Figure S1). Method B: 0-15\% B for $10 \mathrm{~min}$, then $15-30 \%$ B over 35 $\mathrm{min}$ (semipreparative isolation of for-[Zr(PPDFOT 1$)]$ and for$\left.\left[\mathrm{Zr}\left(\mathrm{PPDFOT}_{1 \mathrm{D}}\right)\right]_{2}\right)$. MS isotope patterns were calculated using ChemCalc. ${ }^{65}$

Synthesis of Ligands. for $-\mathrm{PBH}$, for $-\mathrm{PPH}$, for $-\mathrm{HBH}$, ret- $\mathrm{PBH}$, and ret- $\mathrm{HBH}^{34,47}$ or DFOB-for $-\mathrm{PBH}^{32}$ were prepared as described previously. The ligand ret-PPH was prepared from precursors P1P4 (Scheme S1 and Figures S2-S5), with the final step undertaken from $\mathbf{P 4}$ as follows.

4-(6-Amino- $N$-hydroxyhexanamido)butanoic acid (ret-PPH). A sample of $\mathbf{P 4}(100 \mathrm{mg}, 0.23 \mathrm{mmol})$ was dissolved in dichloromethane $(4.5 \mathrm{~mL})$ and trifluoroacetic acid $(0.5 \mathrm{~mL})$ was added. The reaction mixture was stirred for $3 \mathrm{~h}$ and concentrated in vacuo to give a yellow gum. The residue was dissolved in tert-butanol and ethyl acetate mixture $(9: 1,5 \mathrm{~mL})$ and $10 \% \mathrm{Pd} / \mathrm{C}$ was added under a nitrogen atmosphere. The mixture was purged with nitrogen, degassed, purged with hydrogen and then stirred under a hydrogen atmosphere for $8 \mathrm{~h}$. The reaction mixture was quenched with water, filtered through cotton wool and concentrated in vacuo to give the title compound as a yellow gum. Yield: $86 \mathrm{mg}, 93 \% .{ }^{1} \mathrm{H}$ NMR $\left(400 \mathrm{MHz}, \mathrm{CDCl}_{3}\right): \delta 3.66(\mathrm{t}, J=$ $6.8 \mathrm{~Hz}, 2 \mathrm{H}), 2.93(\mathrm{t}, J=7.6 \mathrm{~Hz}, 2 \mathrm{H}), 2.51(\mathrm{t}, J=7.2 \mathrm{~Hz}, 2 \mathrm{H}), 2.32(\mathrm{t}$, $J=7.2 \mathrm{~Hz}, 2 \mathrm{H}), 1.90$ (apparent qn, $J=6.8 \mathrm{~Hz}, 2 \mathrm{H}), 1.62-1.69(\mathrm{~m}$, $4 \mathrm{H}), 1.39-1.47(\mathrm{~m}, 2 \mathrm{H})$ (Figure S6). ${ }^{13} \mathrm{C} \mathrm{NMR}\left(101 \mathrm{MHz}, \mathrm{CDCl}_{3}\right)$ : $\delta 176.9,175.8,49.9,48.3,40.5,32.8,32.0,28.2,27.0,25.1,23.1$ (Figure S7).

Metal-Templated Synthesis. A 1:4 solution of $\mathrm{Zr}(\mathrm{IV})$ (acac) and the endo-hydroxamic acid $(2 \mathrm{mg} / \mathrm{mL}$ concentration with respect to the ligand) was prepared in $1: 1$ methanol $/ \mathrm{H}_{2} \mathrm{O}$ and the solution was stirred for $1 \mathrm{~h}$. The mixture was concentrated to dryness in vacuo and was redissolved in DMF to a concentration of $1 \mathrm{mg} / \mathrm{mL}$ with respect to the ligand. Diphenylphosphoryl azide (6 equiv) and $\mathrm{Et}_{3} \mathrm{~N}$ ( 6 equiv) were added and the mixture was stirred at ambient temperature for 5 days. The reaction mixture was then quenched with cold $\mathrm{H}_{2} \mathrm{O}$ (a volume equal to the volume of DMF). Aliquots $(10 \mu \mathrm{L})$ were analyzed by LC-MS following HPLC method A. The mixture containing for$\left[\mathrm{Zr}\left(\mathrm{DFOT}_{1}\right)\right]$ or the mixture containing for $-\left[\mathrm{Zr}\left(\mathrm{PPDFOT}_{1}\right)\right]$ and for$\left[\mathrm{Zr}\left(\mathrm{PPDFOT}_{1 \mathrm{D}}\right)_{2}\right]$ was further purified as follows. To the reaction mixture was added $\mathrm{H}_{2} \mathrm{O}(10 \mathrm{~mL}$ per $1 \mathrm{~mL}$ reaction mixture $)$ and Dowex $1 \times 8(0.1 \mathrm{~g}$ per $1 \mathrm{~mL}$ of reaction mixture $)$ and was stirred for $24 \mathrm{~h}$. The mixture was filtered and washed with 1:1 DMF/ $\mathrm{H}_{2} \mathrm{O}(2 \times$ $50 \mathrm{~mL}$ ), and the filtrate was concentrated in vacuo. The residue was redissolved in 1:1 DMSO $/ \mathrm{H}_{2} \mathrm{O}$ and purified by semipreparative HPLC following method C. Sufficient quantity of for-[Zr(PPDFOT $\left.\left.{ }_{1}\right)\right]$ was obtained for an ${ }^{1} \mathrm{H}$ NMR spectrum $\left(400 \mathrm{MHz}, \mathrm{CDCl}_{3}\right): \delta 8.39-8.46$ (m, $2.3 \mathrm{H}$, exchange with solvent), 3.87-3.98 $(\mathrm{m}, 4 \mathrm{H}), 3.70-3.83(\mathrm{~m}$, $4 \mathrm{H}, 3.51-3.50(\mathrm{~m}, 4 \mathrm{H}), 3.01-3.12(\mathrm{~m}, 4 \mathrm{H}), 2.63-2.72(\mathrm{~m}, 2 \mathrm{H})$, $1.81-2.26(\mathrm{~m}, 26 \mathrm{H}), 1.48-1.76(\mathrm{~m}, 14 \mathrm{H}), 1.16-1.38(\mathrm{~m}, 12 \mathrm{H})$ (Figure S8).

Stability of $\mathrm{Zr}(\mathrm{IV})$ Complexes. Stock solutions $(1 \mathrm{mg} / \mathrm{mL})$ of for-

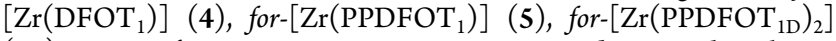
(10), DFOB-for-PBH or DFOB were prepared in methanol. An aliquot $(10 \mu \mathrm{L})$ of the stock solution of the relevant compound was added to an aliquot $(190 \mu \mathrm{L})$ of EDTA $(100 \mathrm{mM})$ at $\mathrm{pH} 4.0$ (Figure 3) or $\mathrm{pH} 7.0$ (Figure 5). Aliquots $(10 \mu \mathrm{L})$ were removed at specified time points and the solutions were analyzed by LC-MS.

Reassembly of $\mathrm{Zr}(\mathrm{IV})$ Complexes. Solutions containing EDTA $(171 \mu \mathrm{L}, 100 \mathrm{mM})$ and for-[Zr(PPDFOT 1$)](5)(9 \mu \mathrm{L}$ of $1 \mathrm{mg} / \mathrm{mL})$ 
or for- $\left[\mathrm{Zr}\left(\mathrm{PPDFOT}_{1 \mathrm{D}}\right)_{2}\right](\mathbf{1 0})(9 \mu \mathrm{L}$ of $1 \mathrm{mg} / \mathrm{mL})$ were $\mathrm{pH}$ adjusted to 4.0 and after $60 \mathrm{~h}$ were purified by HPLC (Method A). PPDFOT (12) was collected from 34.5-39.5 $\mathrm{min}$ and homobisucaberin (11) was collected from $26.5-29.5 \mathrm{~min}$. The fractions were pooled, lyophilized and redissolved in Milli-Q water $(200 \mu \mathrm{L})$. A sample of $\mathrm{PPDFOT}_{1}(12)(10 \mu \mathrm{L})$ or homobisucaberin $(11)$ was mixed with an aliquot $(10 \mu \mathrm{L})$ of $\mathrm{Zr}(\mathrm{acac})_{4}\left(0.25 \mathrm{mg} / \mathrm{mL}\right.$ in $1: 100$ methanol: $\left.\mathrm{H}_{2} \mathrm{O}\right)$ and after incubation for $1 \mathrm{~h}$ was analyzed by LC-MS.

Molecular Mechanics Calculations. Structures of for-[Zr$\left.\left(\mathrm{DFOT}_{1}\right)\right]$ and for-[ $\left.\mathrm{Zr}\left(\mathrm{DFOT}_{1 \mathrm{D}}\right)_{2}\right]$ were built using HyperChem (version 7.5) from the X-ray coordinates of $\mathrm{Zr}(\mathrm{Me}-\mathrm{AHA})_{4}{ }^{15}$ and fragments of for-PBH from $\mathrm{Fe}(\mathrm{III})$-DFOB ${ }^{61}$ Additional methylene groups were inserted for for-[Zr(PPDFOT 1$)]$, for-[Zr(PPDFOT $\left.\left.{ }_{1 \mathrm{D}}\right)_{2}\right]$, for $-\left[\mathrm{Zr}\left(\mathrm{HBDFOT}_{1}\right)\right]$, and for $-\left[\mathrm{Zr}\left(\mathrm{HBDFOT}_{1 \mathrm{D}}\right)_{2}\right]$. Structures beyond atoms that included $\mathrm{Zr}(\mathrm{IV})$ and those in the first $\left(\mathrm{O}_{8}\right)$ and second $\left(\mathrm{C}_{4} \mathrm{~N}_{4}\right)$ coordination spheres were subject to energy minimization, using the AMBER2 force field. Further details and coordinates for all structures are provided (Table S1-S6).

\section{ASSOCIATED CONTENT}

\section{S Supporting Information}

The Supporting Information is available free of charge on the ACS Publications website at DOI: 10.1021/acs.inorgchem.7b00362.

Data is provided for the synthesis of ret-PPH (Scheme 1, Figures S1-S6), the $\mathrm{Zr}(\mathrm{IV})$-based for-PBH MTS system showing for-[ $\left.\mathrm{Zr}\left(\mathrm{DFOT}_{1}\right)\right]$, the linear precursor of for$\left[\mathrm{Zr}\left(\mathrm{DFOT}_{1}\right)\right]$ and $[\mathrm{Zr}(\mathrm{DFOE})]^{+}$(Figure S7), the ${ }^{1} \mathrm{H}$ NMR spectrum of for-[Zr(PPDFOT $\left.\left.{ }_{1}\right)\right]$ (Figure S8); the repeat MTS-based synthesis with for-PPH (Figure S9); HRMS data for for-[Zr(PPDFOT 1$)]$, for- $[\mathrm{Zr}$ $\left.\left(\mathrm{PPDFOT}_{1 \mathrm{D}}\right)_{2}\right], \mathrm{PPDFOT}_{1}$ or $\mathrm{PPDFOT}_{1 \mathrm{D}}$ (HBC) (Figures $\mathrm{S} 10-13$, respectively); the ${ }^{1} \mathrm{H}$ NMR spectrum of DFOB-for-PBH (Figure S14); and the coordinates of the structures of for- $\left[\mathrm{Zr}\left(\mathrm{DFOT}_{1}\right)\right]$, for- $\left[\mathrm{Zr}\left(\mathrm{DFOT}_{1 \mathrm{D}}\right)_{2}\right]$, for- $\left[\mathrm{Zr}\left(\mathrm{PPDFOT}_{1}\right)\right]$, for- $\left[\mathrm{Zr}\left(\mathrm{PPDFOT}_{1 \mathrm{D}}\right)_{2}\right]$, for- $[\mathrm{Zr}-$ $\left.\left(\mathrm{HBDFOT}_{1}\right)\right]$, and for- $\left[\mathrm{Zr}\left(\mathrm{HBDFOT}_{1 \mathrm{D}}\right)_{2}\right]$ (Tables $\mathrm{S} 1-\mathrm{S} 6)(\mathrm{PDF})$

\section{AUTHOR INFORMATION}

\section{Corresponding Author}

*E-mail: rachel.codd@sydney.edu.au.

\section{ORCID $\odot$}

Rachel Codd: 0000-0002-2703-883X

\section{Notes}

The authors declare no competing financial interest.

\section{ACKNOWLEDGMENTS}

The Australian Research Council (DP140100092) is acknowledged for research support to R.C. and A.K. and for salary support to W.T. The University of Sydney is acknowledged for the provision of a postgraduate research award (cofunded) to T.L.

\section{REFERENCES}

(1) Price, E. W.; Orvig, C. Matching chelators to radiometals for radiopharmaceuticals. Chem. Soc. Rev. 2014, 43, 260-290.

(2) Zeglis, B. M.; Houghton, J. L.; Evans, M. J.; Viola-Villegas, N.; Lewis, J. S. Underscoring the influence of inorganic chemistry on nuclear imaging with radiometals. Inorg. Chem. 2014, 53, 1880-1899.

(3) Price, T. W.; Greenman, J.; Stasiuk, G. J. Current advances in ligand design for inorganic positron emission tomography tracers 68Ga, $64 \mathrm{Cu}, 89 \mathrm{Zr}$ and $44 \mathrm{Sc}$. Dalton Trans. 2016, 45, 15702-15724.
(4) Boros, E.; Marquez, B. V.; Ikotun, O. F.; Lapi, S. E.; Ferreira, C. L. In Ligand Design in Medicinal Inorganic Chemistry; Storr, T., Ed.; John Wiley \& Sons, Ltd: Chichester, UK, 2014.

(5) Fischer, G.; Seibold, U.; Schirrmacher, R.; Wängler, B.; Wängler, C. ${ }^{89} \mathrm{Zr}$, a radiometal nuclide with high potential for molecular imaging with PET: chemistry, applications and remaining challenges. Molecules 2013, 18, 6469-6490.

(6) Blower, P. J. A nuclear chocolate box: the periodic table of nuclear medicine. Dalton Trans. 2015, 44, 4819-4844.

(7) Brasse, D.; Nonat, A. Radiometals: towards a new success story in nuclear imaging. Dalton Trans. 2015, 44, 4845-4858.

(8) van Dongen, G. A. M. S.; Huisman, M. C.; Boellaard, R.; Hendrikse, N. H.; Windhorst, A. D.; Visser, G. W. M.; Molthoff, C. F. M.; Vugts, D. J. 89Zr-immuno-PET for imaging of long circulating drugs and disease targets: why, how and when to be applied? Q. J. Nucl. Med. Mol. Imaging 2015, 59, 18-38.

(9) Scharli, R. K.; Price, R. I.; Chan, S.; Cryer, D.; Jeffery, C. M.; Asad, A. H.; Morandeau, L.; Eu, P.; Cullinane, C.; Kasbollah, A.; Katsifis, A. Establishing reliable production of the PET isotope $89 \mathrm{Zr}$ for research use: From target fabrication to preclinical imaging. AIP Conf. Proc. 2012, 1509, 101-107.

(10) Verel, I.; Visser, G. W. M.; Boellaard, R.; Stiger-van Walsum, M.; Snow, G. B.; van Dongen, G. A. M. S. ${ }^{89} \mathrm{Zr}$ immuno-PET: Comprehensive procedures for the production of ${ }^{89} \mathrm{Zr}$-labeled monoclonal antibodies. J. Nucl. Med. 2003, 44, 1271-1281.

(11) Rice, S. L.; Roney, C. A.; Daumar, P.; Lewis, J. A. The next generation of positron emission tomography radiopharmaceuticals in oncology. Semin. Nucl. Med. 2011, 41, 265-282.

(12) Deri, M. A.; Zeglis, B. M.; Francesconi, L. C.; Lewis, J. S. PET imaging with 89Zr: From radiochemistry to the clinic. Nucl. Med. Biol. 2013, 40, 3-14.

(13) Baggio, R.; Garland, M. T.; Perec, M. Preparation and X-ray crystal structure of the polymeric zirconium(IV) oxalate complex $\left[\mathrm{K}_{2}\left\{\mathrm{Zr}\left(\mathrm{C}_{2} \mathrm{O}_{4}\right)_{3}\right\} \cdot \mathrm{H}_{2} \mathrm{C}_{2} \mathrm{O}_{4} \cdot \mathrm{H}_{2} \mathrm{O}\right]_{n}$. Inorg. Chem. 1997, 36, 737-739.

(14) Baroncelli, F.; Grossi, G. The complexing power of hydroxamic acids and its effect on the behaviour of organic extractants in the reprocessing of irradiated fuels. I. The complexes between benzohydroxamic acid and zirconium, iron(III) and uranium(IV). J. Inorg. Nucl. Chem. 1965, 27, 1085-1092.

(15) Guérard, F.; Lee, Y.-S.; Tripier, R.; Szajek, L. P.; Deschamps, J. R.; Brechbiel, M. W. Investigation of $\mathrm{Zr}(\mathrm{IV})$ and ${ }^{89} \mathrm{Zr}(\mathrm{IV})$ complexation with hydroxamates: progress towards designing a better chelator than desferrioxamine B for immuno-PET imaging. Chem. Commun. 2013, 49, 1002-1004.

(16) Codd, R. Traversing the coordination chemistry and chemical biology of hydroxamic acids. Coord. Chem. Rev. 2008, 252, 1387-1408.

(17) Hider, R. C.; Kong, X. Chemistry and biology of siderophores. Nat. Prod. Rep. 2010, 27, 637-657.

(18) Braich, N.; Codd, R. Immobilized metal affinity chromatography for the capture of hydroxamate-containing siderophores and other $\mathrm{Fe}(\mathrm{III})$-binding metabolites from bacterial culture supernatants. Analyst 2008, 133, 877-880.

(19) Ejje, N.; Soe, C. Z.; Gu, J.; Codd, R. The variable hydroxamic acid siderophore metabolome of the marine actinomycete Salinispora tropica CNB-440. Metallomics 2013, 5, 1519-1528.

(20) Meijs, W. E.; Herscheid, J. D. M.; Haisma, H. J.; Pinedo, H. M. Evaluation of desferal as a bifunctional chelating agent for labeling antibodies with Zr-89. Appl. Radiat. Isot. 1992, 43, 1443-1447.

(21) Meijs, W. E.; Haisma, H. J.; Klok, R. P.; van Gog, F. B.; Kievit, E.; Pinedo, H. M.; Herscheid, J. D. Zirconium-labeled monocloncal antibodies and their distribution in tumor-bearing nude mice. J. Nucl. Med. 1997, 38, 112-118.

(22) Börjesson, P. K. E.; Jauw, Y. W. S.; Boellaard, R.; de Bree, R.; Comans, E. F. I.; Roos, J. C.; Castelijns, J. A.; Vosjan, M. J. W. D.; Kummer, J. A.; Leemans, C. R.; Lammertsma, A. A.; van Dongen, G. A. M. S. Performance of immuno-positron emission tomography with zirconium-89-labeled chimeric monoclonal antibody U36 in the detection of lymph node metastases in head and neck cancer patients. Clin. Cancer Res. 2006, 12, 2133-2140. 
(23) van Rij, C. M.; Sharkey, R. M.; Goldenberg, D. M.; Frielink, C.; Molkenboer, J. D.; Franssen, G. M.; van Weerden, W. M.; Oyen, W. J.; Boerman, O. C. Imaging of prostate cancer with immuno-PET and immuno-SPECT using a radiolabeled anti-EPG-1 monoclonal antibody. J. Nucl. Med. 2011, 52, 1601-1607.

(24) Dijkers, E. C. F.; Kosterink, J. G. W.; Rademaker, A. P.; Perk, L. R.; van Dongen, G. A. M. S.; Bart, J.; de Jong, J. R.; de Vries, E. G. E.; Lub-de Hooge, M. N. Development and characterisation of clinicalgrade ${ }^{89} \mathrm{Zr}$-trastuzumab for HER2/neu imminoPET imaging. J. Nucl. Med. 2009, 50, 974-981.

(25) Holland, J. P.; Caldas-Lopes, E.; Divilov, V.; Longo, V. A.; Taldone, T.; Zatorska, D.; Chiosis, G.; Lewis, J. S. Measuring the pharmacodynamic effects of a novel Hsp 90 inhibitor on HER2/neu expression in mice using ${ }^{89} \mathrm{Zr}$-DFO-trastuzumab. PLoS One 2010, 5, e8859.

(26) Petrik, M.; Zhai, C.; Novy, Z.; Urbanek, L.; Haas, H.; Decristoforo, C. In vitro and in vivo comparison of selected Ga-68 adn Zr-89 labelled siderophores. Mol. Imaging Biol. 2016, 18, 344352.

(27) Jauw, Y. W. S.; Menke-van der Houven van Oordt, C. W.; Hoekstra, O. S.; Hendrikse, N. H.; Vugts, D. J.; Zijlstra, J. M.; Huisman, M. C.; van Dongen, G. A. M. S. Immuno-positron emission tomography with zirconium-89-labeled monoclonal antibodies in oncology: waht can we learn from initial clinical trials? Front. Pharmacol. 2016, 7 (131), 15.

(28) Holland, J. P.; Vasdev, N. Charting the mechanism and reactivity of zirconium oxalate with hydroxamate ligands using density functional theory: Implications in new chelate design. Dalton Trans. 2014, 43, 9872-9884.

(29) Holland, J. P.; Divilov, V.; Bander, N. H.; Smith-Jones, P. M.; Larson, S. M.; Lewis, J. S. ${ }^{89}$ Zr-DFO-J591 for immunoPET of prostatespecific membrane antigen expression in vivo. J. Nucl. Med. 2010, 51, $1293-1300$.

(30) Abou, D. S.; Ku, T.; Smith-Jones, P. M. In vivo biodistribution and accumulation of ${ }^{89} \mathrm{Zr}$ in mice. Nucl. Med. Biol. 2011, 38, 675-681.

(31) Nayak, T. K.; Garmestani, K.; Milenic, D. E.; Brechbiel, M. W. PET and MRI of metastatic peritoneal and pulmonary colorectal cancer in mice with human epidermal growth factor receptor 1targeted 89Zr-labeled panitumumab. J. Nucl. Med. 2012, 53, 113-120.

(32) Patra, M.; Bauman, A.; Mari, C.; Fischer, C. A.; Blacque, O.; Haussinger, D.; Gasser, G.; Mindt, T. L. An octadentate bifunctional chelating agent for the development of stable zirconium- 89 based molecular imaging probes. Chem. Commun. 2014, 50, 11523-11525.

(33) Vugts, D. J.; Klaver, C.; Sewing, C.; Poot, A. J.; Adamzek, K.; Huegli, S.; Mari, C.; Visser, G. W. M.; Valverde, I. E.; Gasser, G.; Mindt, T. L.; van Dongen, G. A. M. S. Comparison of the octadentate bifunctional chelator $\mathrm{DFO}^{*}-p$ Phe-NCS and the clinically used hexadentate bifunctional chelator DFO-pPhe-NCS for $89-\mathrm{Zr}$-immuno-PET. Eur. J. Nucl. Med. Mol. Imaging 2017, 44, 286-295.

(34) Kadi, N.; Oves-Costales, D.; Barona-Gomez, F.; Challis, G. L. A new family of ATP-dependent oligomerization-macrocyclization biocatalysts. Nat. Chem. Biol. 2007, 3, 652-656.

(35) Soe, C. Z.; Codd, R. Unsaturated macrocyclic dihydroxamic acid siderophores produced by Shewanella putrefaciens using precursordirected biosynthesis. ACS Chem. Biol. 2014, 9, 945-956.

(36) Telfer, T. J.; Gotsbacher, M. P.; Soe, C. Z.; Codd, R. Mixing up the pieces of the desferrioxamine $\mathrm{B}$ jigsaw defines the biosynthetic sequence catalyzed by DesD. ACS Chem. Biol. 2016, 11, 1452-1462.

(37) Richardson-Sanchez, T.; Tieu, W.; Codd, R. Reverse biosynthesis: Generating combinatorial pools of drug leads from enzymemediated fragmentation of natural products. ChemBioChem 2017, 18, 368-373.

(38) Deri, M. A.; Ponnala, S.; Zeglis, B. M.; Pohl, G.; Dannenberg, J. J.; Lewis, J. S.; Francesconi, L. C. Alternative chelator for ${ }^{89} \mathrm{Zr}$ radiopharmaceuticals: radiolabeling and evaluation of 3,4,3,-(LI-1,2HOPO). J. Med. Chem. 2014, 57, 4849-4860.

(39) Ma, M. T.; Meszaros, L. K.; Paterson, B. M.; Berry, D. J.; Cooper, M. S.; Ma, Y. M.; Hider, R. C.; Blower, P. J. Tripodal tris(hydroxypyridinone) ligands for immunoconjugate PET imaging with ${ }^{89} \mathrm{Zr}^{4+}$ : Comparison with desferrioxamine B. Dalton Trans. 2015 44, 4884-4900

(40) Deri, M. A.; Ponnala, S.; Kozlowski, P.; Burton-Pye, B. P.; Cicek, H. T.; Hu, C.; Lewis, J. S.; Francesconi, L. C. p-SCN-Bn-HOPO: a superior bifunctional chelator for $89 \mathrm{Zr}$ immunoPET. Bioconjugate Chem. 2015, 26, 2579-2591.

(41) Rudd, S. E.; Roselt, P.; Cullinane, C.; Hicks, R. J.; Donnelly, P. $\mathrm{S}$. A desferrioxmaine $\mathrm{B}$ squaramide ester for the incorporation of zirconium-89 into antibodies. Chem. Commun. 2016, 52, 1188911892.

(42) Guérard, F.; Lee, Y.-S.; Brechbiel, M. W. Rational design, synthesis, and evaluation of tetrahydroxamic acid chelators for stable complexation of zirconium(IV). Chem. - Eur. J. 2014, 20, 5584-5591.

(43) Boros, E.; Holland, J. P.; Kenton, N.; Rotile, N. J.; Caravan, P. Macrocycle-based hydroxamate ligands for complexation and immunoconjugation of 89zirconium for positron emission tomography (PET) imaging. ChemPlusChem 2016, 81, 274-281.

(44) McMurry, T. J.; Raymond, K. N.; Smith, P. H. Molecular recognition and metal ion template synthesis. Science 1989, 244, 938943.

(45) McMurry, T. J.; Rodgers, S. J.; Raymond, K. N. Template and stepwise synthesis of a macrobicyclic catechoylamide ferric ion sequestering agent. J. Am. Chem. Soc. 1987, 109, 3451-3453.

(46) Kachadourian, R.; Chuilon, S.; Mérienne, C.; Kunesch, G.; Deroussent, A. A New Total Synthesis of Ferrioxamine E through Metal-templated Cyclic Trimerization. Supramol. Chem. 1997, 8, 301308

(47) Lifa, T.; Tieu, W.; Hocking, R. K.; Codd, R. Forward and reverse (retro) iron(III)- or gallium(III)-desferrioxamine $\mathrm{E}$ and ringexpanded analogs prepared using metal-templated synthesis from endohydroxamic acid monomers. Inorg. Chem. 2015, 54, 3573-3583.

(48) Giordanetto, F.; Kihlberg, J. Macrocyclic drugs and clinical candidates: What can medicinal chemists learn from their properties? J. Med. Chem. 2014, 57, 278-294.

(49) Driggers, E. M.; Hale, S. P.; Lee, J.; Terrett, N. K. The exploration of macrocycles for drug discovery - an underexploited structural class. Nat. Rev. Drug Discovery 2008, 7, 608-624.

(50) Marsault, E.; Peterson, M. L. Macrocycles are great cycles: Applications, opportunities, and challenges of synthethic macrocycles in drug discovery. J. Med. Chem. 2011, 54, 1961-2004.

(51) Heinis, C. Drug discovery. Tools and rules for macrocycles. Nat. Chem. Biol. 2014, 10, 696-698.

(52) Marti-Centelles, V.; Pandey, M. D.; Burguete, M. I.; Luis, S. V. Macrocyclization reactions: the importance of conformational, configurational, and template-induced preorganisation. Chem. Rev. 2015, 115, 8736-8834.

(53) Marti-Centelles, V.; Burguete, M. I.; Luis, S. V. Macrocycle synthesis by chloride-templated amide bond formation. J. Org. Chem. 2016, 81, 2143-2147.

(54) Feistner, G. J.; Stahl, D. C.; Gabrik, A. H. Proferrioxamine siderophores of Erwinia amylovora. A capillary liquid chromatographic/electrospray tandem mass spectrometric study. Org. Mass Spectrom. 1993, 28, 163-175.

(55) Nishio, T.; Tanaka, N.; Hiratake, J.; Katsube, Y.; Ishida, Y.; Oda, $\mathrm{J}$. Isolation and structure of the novel dihydroxamate siderophore alcaligin. J. Am. Chem. Soc. 1988, 110, 8733-8734.

(56) Takahashi, A.; Nakamura, H.; Kameyama, T.; Kurasawa, S.; Naganawa, H.; Okami, Y.; Takeuchi, T.; Umezawa, H.; Iitaka, Y. Bisucaberin, a new siderophore, sensitizing tumor cells to macrophagemediated cytolysis. II. Physico-chemical properties and structure determination. J. Antibiot. 1987, 40, 1671-1676.

(57) Ledyard, K. M.; Butler, A. Structure of putrebactin, a new dihydroxamate siderophore produced by Shewanella putrefaciens. JBIC, J. Biol. Inorg. Chem. 1997, 2, 93-97.

(58) Soe, C. Z.; Pakchung, A. A. H.; Codd, R. Directing the biosynthesis of putrebactin or desferrioxamine B in Shewanella putrefaciens through the upstream inhibition of ornithine decarboxylase. Chem. Biodiversity 2012, 9, 1880-1890. 
(59) Boettcher, T.; Clardy, J. A chimeric siderophore halts swarming Vibrio. Angew. Chem., Int. Ed. 2014, 53, 3510-3513.

(60) Soe, C. Z.; Telfer, T. J.; Levina, A.; Lay, P. A.; Codd, R. Simultaneous biosynthesis of putrebactin, avaroferrin and bisucaberin by Shewanella putrefaciens and characterisation of complexes with iron(III), molybdenum(VI) or chromium(V). J. Inorg. Biochem. 2016, 162, 207-215.

(61) Dhungana, S.; White, P. S.; Crumbliss, A. L. Crystal structure of ferrioxamine B: A comparative analysis and implications for molecular recognition. JBIC, J. Biol. Inorg. Chem. 2001, 6, 810-818.

(62) Bergeron, R. J.; McManis, J. S. The total synthesis of desferrioxamines E and G. Tetrahedron 1990, 46, 5881-5888.

(63) Bergeron, R. J.; McManis, J. S.; Phanstiel, O. I.; Vinson, J. R. T. A versatile synthesis of deferrioxamine B. J. Org. Chem. 1995, 60, 109114.

(64) Wencewicz, T. A.; Oliver, A. G.; Miller, M. J. Iron(III)templated macrolactonization of trihydroxamate siderophores. Org. Lett. 2012, 14, 4390-4393.

(65) Patiny, L.; Borel, A. ChemCalc: a building block for tomorrow's chemical infrastructure. J. Chem. Inf. Model. 2013, 53, 1223-1228. 